\title{
Hyperinsulinemic hypoglycemia in children and adolescents: Recent advances in understanding of pathophysiology and management
}

\author{
Maria Güemes ${ }^{1,2,3}$. Sofia Asim Rahman ${ }^{1}$. Ritika R. Kapoor ${ }^{4}$. Sarah Flanagan ${ }^{5}$ • Jayne A. L. Houghton ${ }^{5,6}$. \\ Shivani Misra ${ }^{7} \cdot$ Nick Oliver $^{7} \cdot$ Mehul Tulsidas Dattani $^{1,2} \cdot$ Pratik Shah $^{1,2}$ (D)
}

Published online: 17 March 2020

(C) The Author(s) 2020

\begin{abstract}
Hyperinsulinemic hypoglycemia $(\mathrm{HH})$ is characterized by unregulated insulin release, leading to persistently low blood glucose concentrations with lack of alternative fuels, which increases the risk of neurological damage in these patients. It is the most common cause of persistent and recurrent hypoglycemia in the neonatal period. HH may be primary, Congenital $\mathrm{HH}(\mathrm{CHH})$, when it is associated with variants in a number of genes implicated in pancreatic development and function. Alterations in fifteen genes have been recognized to date, being some of the most recently identified mutations in genes HK1, PGM1, PMM2, CACNA1D, FOXA2 and EIF2S3. Alternatively, HH can be secondary when associated with syndromes, intra-uterine growth restriction, maternal diabetes, birth asphyxia, following gastrointestinal surgery, amongst other causes. CHH can be histologically characterized into three groups: diffuse, focal or atypical. Diffuse and focal forms can be determined by scanning using fluorine-18 dihydroxyphenylalanine-positron emission tomography. Newer and improved isotopes are currently in development to provide increased diagnostic accuracy in identifying lesions and performing successful surgical resection with the ultimate aim of curing the condition. Rapid diagnostics and innovative methods of management, including a wider range of treatment options, have resulted in a reduction in co-morbidities associated with $\mathrm{HH}$ with improved quality of life and long-term outcomes. Potential future developments in the management of this condition as well as pathways to transition of the care of these highly vulnerable children into adulthood will also be discussed.
\end{abstract}

Keywords Hyperinsulinism $\cdot$ Hypoglycemia $\cdot$ Sirolimus $\cdot$ Lanreotide $\cdot 18$ F-DOPA-PET $\cdot$ Transition to adult services

Pratik Shah

pratik.shah6@nhs.net; drshahp@gmail.com

1 Genetics and Genomic Medicine Programme, UCL Great Ormond Street Institute of Child Health, Great Ormond Street, London WC1N 3JH, UK

2 Department of Pediatric Endocrinology, Great Ormond Street Hospital for Children, London, UK

3 Endocrinology Service, Hospital Infantil Universitario Niño Jesús, Madrid, Spain

4 Pediatric Diabetes and Endocrinology, King's College Hospital NHS Trust, Denmark Hill, London, UK

5 Institute of Biomedical and Clinical Science, University of Exeter Medical School, Exeter, UK

6 Royal Devon and Exeter Foundation Trust, Exeter, UK

7 Department of Diabetes, Endocrinology and Metabolic Medicine, Faculty of Medicine, Imperial College Healthcare NHS Trust, London, UK

\section{Introduction}

Glucose is one of the principal energy substrates, providing half of the body's total energy requirements. As the brain can neither synthesize nor store more than a few minutes supply of glucose, its function is solely dependent on maintenance of normal glucose concentrations in the circulation. An abnormally reduced concentration of glucose in the blood is referred to as hypoglycemia. It is a medical emergency and can lead to symptoms due to neuroglycopenia [1].

In healthy individuals, maintenance of a normal plasma glucose concentration relies on a tightly controlled balance between glucose production (dietary intake, glycogenolysis, gluconeogenesis) and its utilization by the tissues (glycolysis, glycogenesis, conversion to fatty acids). A normal endocrine system is essential for integrating and modulating substrate mobilization, interconversion, and utilization. In addition, the endocrine system interacts with metabolic pathways that rely critically on functionally intact enzymes. There are two 
types of metabolic hormones affecting blood glucose concentrations - an anabolic hormone (insulin), which decreases blood glucose, and several catabolic hormones (such as glucagon, cortisol and catecholamines) which increase blood glucose concentrations.

Hyperinsulinemic hypoglycemia $(\mathrm{HH})$ is the commonest cause of persistent hypoglycemia in infants and children [2] and it can be transient-associated to risk factors- or permanent -linked to genetic mutations-. The risk of permanent brain injury in infants with $\mathrm{HH}$ continues to be as high as 25-50\% due to delays in diagnosis and inadequate treatment. Despite advances in genetics, improved modes of investigation, novel management options and abrigding pediatric and adult followup in holistic multidisciplinary transition clinics, significant morbidity and mortality is still a major issue in children and young adults with $\mathrm{HH}[3-5]$.

The present review has been written using a comprehensive and up-to-date literature search on congenital hyperinsulinism/HH including the latest publications available in PubMed (last search in August 2019). It also incorporates clinical and laboratory experience from reference centers for the diagnosis and management of $\mathrm{HH}$, as well as available data from on-going pharmaceutical trials.

\section{2 normal blood glucose and hypoglycemia}

\subsection{Definition of normal blood glucose}

Blood glucose concentrations of normal term neonates appropriate for gestational age may range between $1.4-6.2 \mathrm{mmol} / \mathrm{l}$ $(25-112 \mathrm{mg} / \mathrm{dl})$ during the first $72 \mathrm{~h}$ of life; however after that, healthy children and adults will maintain blood glucose concentrations between $3.5-5.5 \mathrm{mmol} / \mathrm{l}(63-99 \mathrm{mg} / \mathrm{dl})$ [6]. It is difficult to numerically define hypoglycemia given that a single cut-off value cannot suit all individuals in every situation. Therefore operational thresholds are recommended which indicate that in any baby with clinical signs of hypoglycemia, blood glucose levels must be maintained over $2.6 \mathrm{mmol} / \mathrm{l}$ $(47 \mathrm{mg} / \mathrm{dl})$ except for suspected cases of hyperinsulinemic hypoglycemia in which $3.5 \mathrm{mmol} / \mathrm{l}(63 \mathrm{mg} / \mathrm{dl})$ should be the cut-off point [7]. However, the Pediatric Endocrinology Society recommends that when a congenital disorder causing hypoglycemia is suspected in a neonate and when confirmed in older infants and children, the aim is to keep plasma glucose concentrations over $3.9 \mathrm{mmol} / \mathrm{l}(70 \mathrm{mg} / \mathrm{dl})$ [7].

\subsection{Causes of hypoglycemia}

For hypoglycemia to occur, the rate of appearance of glucose into the plasma space must be less than its rate of utilization [8]. This can be due to defective glucose production, increased glucose utilization, or some combination of the two. Excessive glucose utilization due to hyperinsulinism (exogenous/endogenous) is one of the commonest causes of hypoglycemia. Hypoglycemia can also occur due to deficiencies of various counter regulatory hormones. The causes are collected in Table 1.

Hereditary disorders caused by deficiency of specific enzymes involved in mobilization, interconversion, or utilization of metabolic substrates frequently are associated with hypoglycemia. These enzymatic defects may involve carbohydrate, amino acid, or fat metabolism and are individually rare; almost all are inherited as autosomal recessive traits [8].

\section{HYPERINSULINEMIC hypoglycemia (HH)}

$\mathrm{HH}$ is a condition caused by the upregulation of $\beta$-cell secretion of insulin producing a hypoglycemic state. Congenital hyperinsulinism (CHH) is the most common cause of transient or permanent hypoglycemia and could potentially be life threatening causing neurological damage. Hence it requires quick and effective treatment and management [8]. This disorder is rare and has an incidence of around 1:40,000 births in the general population [15]. CHH can occur due to genetic mutations and one of the most common causes are defects in the $\beta$ cell ATP-sensitive potassium $\left(\mathrm{K}_{\text {ATP }}\right)$ channels, known as channelopathies [8]. $\mathrm{K}_{\text {ATP }}$ channels are comprised of two subunits; the inward rectifying Kir6.2 channels and the sulphonylurea receptor-1, SUR-1, which are encoded for by the KCNJ11 (potassium voltage-gated channel subfamily $\mathrm{J}$ member 11 ) and $A B C C 8$ (ATPbinding cassette transporter sub-family $\mathrm{C}$ member 8 ) genes, respectively [16]. Both these subunits are sensitive to the ADP/ATP nucleotide ratio and work together to promote cell depolarization and eventual insulin secretion. Mutations in the KCNJ11/ABCC8 genes are known to cause defects in biogenesis/trafficking of these subunits to the plasma membrane, thus causing $\mathrm{HH}$.

\section{Causes of $\mathrm{HH}$}

\subsection{Transient forms of $\mathrm{HH}$}

Transient $\mathrm{HH}$ is a poorly defined term that refers to the group of patients in whom $\mathrm{HH}$ spontaneously resolves within a few days to approximately a week. However, the cohort includes children requiring medications up to 6 months of life and is usually negative for a known genetic etiology for $\mathrm{HH}$ [17]. It is associated with intrauterine growth retardation, erythroblastosis fetalis, perinatal asphyxia, maternal diabetes mellitus (gestational or 
Table 1 Endocrine and metabolic causes of Hypoglycemia Specific pathologies affecting main metabolic and endocrine pathways that can lead to hypoglycemia $[5,9-14,61,63]$

\begin{tabular}{|c|c|}
\hline \multirow[t]{13}{*}{ Hyperinsulinism } & $\underline{\text { Transient }}$ \\
\hline & Infant of diabetic mother \\
\hline & Perinatal asphyxia \\
\hline & Rhesus hemolytic disease \\
\hline & Intrauterine growth restriction \\
\hline & $H N F 4 A / H N F 1 A$ \\
\hline & Congenital \\
\hline & $\begin{array}{l}\text { ABCC8/KCNJ11/GCK/GDH/HADH/ HNF4A/HNF1A/UCP2/ } \\
\text { SLC16A1/PMM2/HK1/PGM1/FOXA2/CACNA1D/EIF2S3 }\end{array}$ \\
\hline & Others \\
\hline & Post-prandial hyperinsulinemic hypoglycemia \\
\hline & Insulinoma \\
\hline & Munchausen's by proxy \\
\hline & Exercise induced hyperinsulinemic hypoglycemia \\
\hline Hypoinsulinemic hypoglycemia & Activating $A K T 2$ mutations \\
\hline \multirow{2}{*}{$\begin{array}{l}\text { Counter-regulatory hormone } \\
\text { deficiency }\end{array}$} & Growth hormone deficiency \\
\hline & Adrenal insufficiency \\
\hline \multirow[t]{3}{*}{ Fatty acid oxidation disorders } & Medium chain acyl-CoA dehydrogenase deficiency \\
\hline & Long chain acyl-CoA dehydrogenase deficiency \\
\hline & Short chain acyl-CoA dehydrogenase deficiency \\
\hline \multirow{2}{*}{$\begin{array}{l}\text { Defects in ketone body } \\
\text { synthesis/ utilization }\end{array}$} & HMG CoA synthase deficiency \\
\hline & HMG CoA lyase deficiency \\
\hline \multirow{2}{*}{$\begin{array}{l}\text { Carnitine deficiency (primary } \\
\text { and secondary) }\end{array}$} & Carnitine palmitoyl transferase deficiency \\
\hline & (CPT 1 and 2), Carnitine deficiency \\
\hline \multirow[t]{3}{*}{ Gluconeogenic disorders } & Fructose-1, 6-bisphosphatase deficiency, \\
\hline & Phosphoenolpyruvate carboxykinase (PEPCK) deficiency \\
\hline & Pyruvate carboxylase deficiency \\
\hline \multirow[t]{3}{*}{ Glycogen storage disorders } & Glucose-6-phosphatase deficiency \\
\hline & Amylo 1-6 glucosidase deficiency \\
\hline & Glycogen synthase deficiency \\
\hline Defects in glucose transport & GLUT $1 / 2 / 3$ transporters defects \\
\hline \multirow[t]{3}{*}{ Other metabolic conditions } & $\begin{array}{l}\text { Galactosemia, Fructosemia, Tyrosinemia, Glutaric aciduria type 2, Maple } \\
\text { syrup urine disease, Propionic academia }\end{array}$ \\
\hline & Adenosine kinase deficiency \\
\hline & Mitochondrial respiratory chain disease \\
\hline
\end{tabular}

insulin dependent) and after the maternal administration of drugs such as sulphonylureas, and intravenous glucose infusions during labor [2]. Abnormal neurodevelopment is evident in one third of children with transient forms of $\mathrm{HH}$ associated with perinatal risk factors [5].

\subsection{Permanent form of HH}

A permanent form of $\mathrm{HH}$, usually congenital $(\mathrm{CHH})$, is where children continue to need medical treatment even after 6 months of age. Various genetic causes have been identified, however nearly $40-50 \%$ of children still remain genetically unidentified [17].

\subsubsection{Molecular basis of $\mathrm{CHH}$}

To date, at least 15 genes have been identified to be accompanied with $\mathrm{CHH}$, which include $A B C C 8, K C N J 11$, GLUD1, GCK, HADH, SLC16A1, UCP2, HNF1A, HNF4A, HK1, PGM1, PMM2, FOXA2, CACNA1D and EIF2S3.

Various modes of inheritance are observed. For some patients specific clinical characteristics, such as the presence of hyperammonemia, can help guide molecular testing; however, for most of the genetic subgroups there is an overlap in phenotype and as such testing of all the known genes is often required.

$\mathrm{K}_{\mathrm{ATP}}$ channel genes ( $A B C C 8$ and $\left.K C N J 11\right)$ The pancreatic $\mathrm{K}_{\mathrm{ATP}}$ channel is a key component of the insulin secretion pathway. 


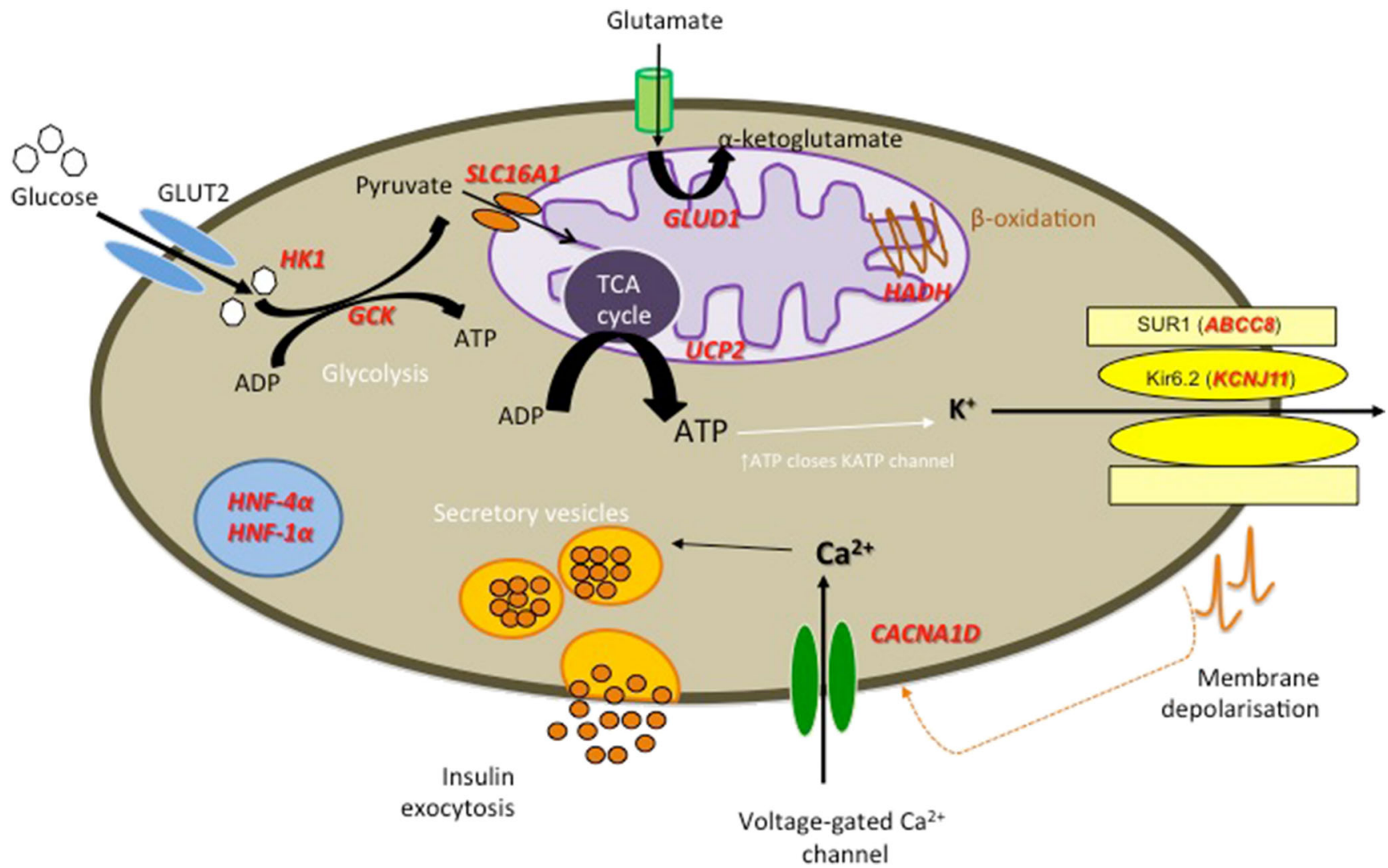

Fig. 1 Diagrammatic representation of $\beta$-cell function. Genetic defects associated with $\mathrm{CHH}$ are included in red. Postprandial glucose is taken into the $\beta$-cells via the glucose transporter 2 (GLUT2). Glucose then enters the glycolysis pathway followed by mitochondrial citric acid cycle (TCA) yielding the high-energy molecule, adenosine triphosphate (ATP). ATP molecules travel to and inhibit the potassium-dependent ATP channels $\left(\mathrm{K}_{\mathrm{ATP}}\right)$, which prevents influx of potassium resulting in membrane depolarization. This triggers voltage-gated calcium channels to open and influx of calcium $\left(\mathrm{Ca}^{2+}\right)$ occurs. The $\mathrm{Ca}^{2+}$ activates the enzyme phospholipase C (PLC) to produce inositol 1, 3, 5 triphosphate $\left(\mathrm{IP}_{3}\right)$ and diacylglycerol (DAG) from phosphatidyl 1, 3 bisphosphate $\left(\mathrm{PIP}_{2}\right)$. The IP3 molecule binds to the protein receptor on the endoplasmic reticulum (ER) to promote a release of $\mathrm{Ca}^{2+}$ from the ER. This subsequently increase in cytoplasmic $\mathrm{Ca}^{2+}$ promotes exocytosis of the pre-packaged mature insulin and active C-peptide, which are released into circulation.

Following glycolysis ATP binds to and closes the $\mathrm{K}_{\text {ATP }}$ channel causing membrane depolarization, opening of calcium channel and insulin exocytosis (Fig. 1). Loss of function variants in $A B C C 8$ and KCNJ11 are the most common cause of $\mathrm{HH}$ accounting for $40-50 \%$ of cases [17-19](OMIM \#601820 and \#256450). These variants exert their effects by 1) leading to a loss of $\mathrm{K}_{\mathrm{ATP}}$ channels at the plasma membrane via effects on gene expression, protein synthesis, protein maturation, or membrane trafficking or 2) by impairing the ability of SUR1 to regulate channel activity by reducing or abolishing channel activation by MgADP and/or MgATP [20, 21]. Recessively inherited variants are the most common and usually result in medically unresponsive HH. Dominant variants in both genes have also been reported [22-24]. The functionally more severe dominant variants cause diazoxide unresponsive $\mathrm{HH}$ requiring near-total
GLUT2: Glucose transporter 2; Glucokinase (GCK) encoded by GCK gene; ADP: Adenosine diphosphate; ATP: Adenosine triphosphate; Monocarboxylate transporter (MCT1) encoded by SLC16Al gene; Glutamate dehydrogenase (GDH) encoded by GLUD1 gene; Uncoupling protein 2 (UCP2) encoded by UCP2 gene; L-3hydroxyacyl-coenzyme A dehydrogenase (HADH) encoded by $H A D H$ gene; SUR1 subunit of the $\mathrm{K}_{\mathrm{ATP}}$ channel encoded by the $A B C C 8$ gene; Kir6.2 subunit of the $\mathrm{K}_{\text {ATP }}$ channel encoded by KCNJ11 gene; Hepatocyte nuclear factor $4 \alpha$ (HNF $4 \alpha$ ) encoded by $H N F 4 A$ gene; Hepatocyte nuclear factor $1 \alpha$ (HNF $1 \alpha)$ encoded by HNF1A gene; HK1: Hexokinase 1 encoded by the gene HK1; CACNA1D: calcium voltage-gated channel subunit alphal D. Mutations in Forkhead Box Protein A2 (FOXA2), Phosphoglucomutase 1 (PGM1) and Phosphomannomutase 2 (PMM2) are not included in the cartoon.

pancreatectomy whilst milder variants cause diazoxideresponsive $\mathrm{HH}$ [25]. In some of the milder cases a bi-phasic phenotype has been reported whereby HH remits in childhood and diabetes is diagnosed in adulthood [26].

Glutamate dehydrogenase (GLUD1) Gain of function mutations in GLUD1 gene, which encodes the mitochondrial enzyme glutamate dehydrogenase (GDH), cause leucinesensitive HH (OMIM \#606762) [27]. Within the pancreatic $\beta$-cell, leucine can activate GDH to catalyze the oxidative deamination of glutamate to $\alpha$-ketoglutarate and ammonia. Aketoglutarate then enters the tricarboxylic acid cycle (TCA) which generates ATP, ultimately leading to insulin exocytosis. Disease-causing variants in GLUD1 cluster around allosteric binding sites and act to reduce the sensitivity of GDH to 
inhibition by GTP and ATP [28]. This loss of regulation leads to an increase in the activity of GDH, a subsequent increase in the amount of $\alpha$-ketoglutarate entering the TCA cycle and consequently an unregulated insulin secretory response.

Individuals with GLUD1 variants usually present with a milder form of $\mathrm{HH}$ that is often diagnosed outside of the neonatal period and is diazoxide-responsive [27]. In some patients dietary protein restriction may also be required. A consistent feature of this disorder is the presence of plasma ammonium concentrations raised two to three times the upper limit of normal. The presence of persistent hyperammonemia, in most but not all patients with GLUD1 variants [29], has led to this subtype of hyperinsulinism being referred to as Hyperinsulinism/Hyperammonemia (HI/HA) syndrome (OMIM \#606762). An increased risk of epilepsy has also been observed in individuals with disease-causing GLUD1 variants [29].

In the majority of cases GLUD1 variants arise de novo, with no family history of hyperinsulinism. In keeping with their dominant nature, $50 \%$ of future offspring of affected individuals are at risk of inheriting the variant and developing $\mathrm{HH}$.

Glucokinase (GCK) Within the pancreatic $\beta$-cell glucokinase $(G C K)$ plays a key role in linking insulin secretion to a glucose challenge by facilitating the phosphorylation of glucose to glucose-6-phosphate, the first step in glycolysis. Heterozygous gain-of-function variants in $G C K$ cause $\mathrm{HH}$ by increasing the affinity of GCK for glucose which then acts to lower the threshold for glucose-stimulated insulin secretion [30] (OMIM \#602485).

Individuals with gain-of-function $G C K$ variants will often have a dominant family history of $\mathrm{HH}$. The absence of a family history should however not preclude testing as de novo variants have been reported [31]. Variability in the severity of $\mathrm{HH}$ is also observed both in terms of age at presentation, which can range from birth to adulthood, and treatment response [31, 32]. Whilst the majority of individuals are successfully treated with diazoxide, some patients have medically unresponsive $\mathrm{HH}$ and require near-total pancreatectomy [32]. Although these differences in phenotype are likely to correlate with the functional severity of the variant, phenotypic variability within families with the same variant has been observed and is likely to be a consequence of genetic background and/ or environmental factors [33].

\section{Hydroxyacyl-coenzyme a dehydrogenase (HADH) HADH en-} codes 3-Hydroxyacyl-coenzyme A dehydrogenase, an intramitochondrial enzyme that catalyzes the penultimate reaction in the $\beta$-oxidation pathway. Loss-of-function variants in $H A D H$ result in loss of interaction between $\mathrm{HADH}$ and glutamate dehydrogenase $[34,35]$. This in turn leads to an increase in glutamate dehydrogenase activity, a subsequent rise in intracellular ATP and upregulated insulin secretion [36].

Patients with $H A D H$ disease-causing variants present with diazoxide-responsive protein-induced HH [36-38](OMIM \#609975). The severity in phenotype ranges from mild late onset hypoglycemia to severe neonatal hypoglycemia. In some patients there are raised plasma concentrations of 3hydroxybutyrylcarnitine and urinary 3-hydroxyglutaric acid [36]. Loss- of- function variants in $H A D H$ are recessively inherited and this is the most common genetic subtype of $\mathrm{HH}$ in consanguineous individuals [39].

Hepatocyte nuclear factors (HNF4A and HNF1A) The hepatocyte nuclear transcription factors, HNF1A and HNF4A, play crucial roles in glucose-stimulated insulin secretion as evidenced by the identification of loss-of- function variants in these genes in individuals with maturity-onset diabetes of the young (MODY)(OMIM \#125850), an autosomal dominant form of diabetes typically diagnosed before the age of 25 years [40]. HNF4A variants were reported to cause a biphasic phenotype in individuals presenting with macrosomia and transient $\mathrm{HH}$ during the neonatal period and diabetes in later life [41]. The duration of $\mathrm{HH}$ varies markedly with some patients treated with intravenous glucose infusion for 12 days, yet others require diazoxide treatment for up to 11 years [42-44]. HH with Fanconi syndrome, a renal tubular dysfunction, has been reported in at least 8 patients with HNF4A HH, all individuals have the p.R76W variant suggesting that this is a mutation specific phenotype [45-48]. A few cases with $H N F 1 A$ variants and transitory neonatal hypoglycemia have also been reported [45, 49].

Whilst a dominant family history of macrosomia, neonatal hypoglycemia and/or young onset diabetes can help to guide genetic testing for this condition, the absence of affected family members should not preclude analysis of HNF4A as de novo disease-causing variants have been reported [43].

Solute carrier family 16 member 1 (SLC16A1) SLC16A1 gene encodes the monocarboxylate transporter (MCT1) which transports the insulin secretagogues pyruvate and lactate. Under normal physiological conditions SLC16A1 is not expressed in the $\beta$-cell thus preventing insulin from being secreted in response to lactate and pyruvate. Rare activating dominant variants result in the expression of MCT1 in the $\beta$ cell leading to pyruvate-stimulated insulin secretion following exercise [50, 51] (OMIM \#610021). For patients with exercise-induced $\mathrm{HH}$, treatment is not usually necessary as hypoglycemic episodes may be prevented by avoiding strenuous exercise [52].

Uncoupling protein 2 (UCP2) UCP2 gene encodes an inner mitochondrial carrier protein UCP2 which is widely expressed in tissues, including pancreatic islets $[53,54]$. UCP2 can 
inhibit ATP generation by causing proton leak across the inner mitochondrial membrane and negatively regulates glucosemediated insulin secretion [54]. Inactivating heterozygous mutations in the $U C P 2$ gene can enhance glucose oxidation and increase intracellular ATP synthesis leading to HH [54]. $U C P 2$ mutations can present with either transient or prolonged $\mathrm{HH}$ [55]. However, in a recent published study, no mutations were detected in the UCP2 gene among 206 diazoxide responsive patients [56], suggesting that the role of UCP2 in HH needs further investigation.

Hexokinase 1 (HK1) HK1 encodes the hexokinase HK1, which catalyzes the phosphorylation of glucose to glucose-6-phosphate as substrate for glycolysis. A family with dominant gain-offunction mutation in the $H K 1$ gene has been reported with "idiopathic hypoglycemia of infancy" [57]. In vitro studies evaluating pancreatic $\beta$-cells from $\mathrm{CHH}$ patients have shown inappropriate expression of HK1. These pancreatic tissues showed functional $\mathrm{K}_{\text {ATP }}$ channels with inappropriate secretion of insulin at low plasma glucose concentrations $(1 \mathrm{mmol} / \mathrm{L})$ [58].

Phosphoglucomutase 1 (PGM1) PGM1 is involved in glycogen metabolism and is responsible for reversible conversion of glucose-6-phosphate to glucose-1-phosphate. $P G M 1$ gene encodes the enzyme PGM1 and recessive loss-of-function mutations in PGM1 cause hypoglycemia [59].

Children with $P G M 1$ mutation presented with postprandial $\mathrm{HH}$ and fasting hyperketotic hypoglycemia [59].

Phosphomannomutase 2 (PMM2) Recessively inherited variants in PMM2, which encodes a key enzyme in N-glycosylation, have been identified in individuals with $\mathrm{HH}$ and polycystic kidney disease. In all individuals a c.-167G > T promotor variant was identified that was either homozygous or in trans with a coding variant [60].

The majority of patients with $P M M 2$ variants present with macrosomia at birth and hypoglycemia in the first year of life. For many, hypoglycemia was the presenting feature and often manifested with seizures. Patients are responsive to treatment with diazoxide [60].

Forkhead box protein A2 (FOXA2) Mutations in FOXA2 have been reported to cause hypopituitarism, $\mathrm{CHH}$ and endodermderived organ abnormalities. These children have a unique clinical phenotype of hypopituitarism, $\mathrm{CHH}$, dysmorphic features, and liver, pancreas, heart and gastrointestinal abnormalities [61, 62].

Calcium voltage-gated channel subunit alpha1 D (CACNA1D) $C A C N A 1 D$ gene encodes an L-type voltage-gated calcium channel which is expressed in pancreatic $\beta$-cells and regulates insulin secretion. Mutations in $C A C N A 1 D$ have been reported to cause $\mathrm{HH}$, heart defects and severe hypotonia [63].
Eukaryotic translation initiation factor 2 subunit 3 (EIF2S3) Three cases published with variant in EIF2S3 present an unusual dysregulation of glucose fluctuating between diazoxideresponsive $\mathrm{HH}$ and postprandial hyperglycemia, along with learning difficulties and hypopituitarism [64].

\subsection{Other forms}

\subsubsection{Postprandial forms of $\mathrm{HH}$}

In postprandial hyperinsulinemic hypoglycemia (PPHH), hypoglycemia is induced hours after meal intake due to inappropriate/exaggerated insulin secretion in response to the meal. The most common cause is "dumping" syndrome in infants/children who have undergone Nissen fundoplication/gastric bypass $[65,66]$. Children with PPHH after Nissen fundoplication have an abnormally exaggerated secretion of the insulin secretagogue glucagon-like peptide 1 (GLP-1) which may contribute to the exaggerated insulin surge and resultant hypoglycemia [67].

PPHH is also reported in the insulin autoimmune syndrome leading to development of insulin binding autoantibodies in children who were not previously exposed to exogenous insulin [68].

\subsubsection{Other causes of $\mathrm{HH}$}

Insulinoma is a rare cause of hyperinsulinism and must be considered in older children or adolescents presenting with HH [69]. A detailed family history of tumors especially like insulinoma, is relevant as it can be part of multiple endocrine neoplasia syndrome type 1 (MEN1).

Munchausen by proxy leading to exogenous administration of insulin or anti-diabetic drugs such as sulphonylureas can present as factitious $\mathrm{HH}$. This has led to misdiagnosis and consequent pancreatectomy [70].

\subsubsection{Syndromes associated with HH}

A large number of syndromes are associated with $\mathrm{HH}$, with Beckwith-Wiedemann syndrome (BWS) being one of the commonest [71]. Table 2 lists the syndromic associations with $\mathrm{HH}$, although the exact mechanism for $\mathrm{HH}$ is still not well understood in all the conditions. Most syndromic forms are diazoxide-reponsive and $\mathrm{HH}$ resolves overtime.

\section{Pathophysiology of HH - histological subtypes}

There are three histological forms of CHH (Fig. 2); Focal form (F-CHH), Diffuse form (D-CHH) and atypical. The clinical presentation appears to be similar, although their molecular mechanisms are quite different. In most cases D-CHH is 
Table 2 Syndromic forms of $\mathrm{HH}$ - Various developmental syndromes have been described with the gene/s linked to the condition and the common clinical features [203]

\begin{tabular}{|c|c|c|}
\hline SYNDROME NAME & $\begin{array}{l}\text { GENETIC ETIOLOGY } \\
\text { gene (location) }\end{array}$ & CLINICAL CHARACTERISTICS \\
\hline \multicolumn{3}{|c|}{ Pre- and postnatal overgrowth (Macrosomia) } \\
\hline Beckwith-Wiedemann & $(11 \mathrm{p} 15)$ & $\begin{array}{l}\text { Macroglossia, abdominal wall defects, ear lobe } \\
\text { pits/ creases, hemihypertrophy, tumor risk }\end{array}$ \\
\hline Sotos & NSD1 (5q35) & $\begin{array}{l}\text { Macrocephaly, frontal bossing, pointed chin, } \\
\text { developmental delay, tumor risk }\end{array}$ \\
\hline Simpson-Golabi-Behmel & $\begin{array}{l}\text { GPC3 (Xq26) } \\
\quad \text { GPC4 (Xp22) }\end{array}$ & $\begin{array}{l}\text { Coarse facial features, broad feet, polydactyly, } \\
\text { cryptorchidism, hepatomegaly, tumor risk }\end{array}$ \\
\hline Perlman & $D I S 3 L 2(2 \mathrm{q} 37)$ & $\begin{array}{l}\text { Inverted V-shaped upper lip, prominent forehead, } \\
\text { developmental delay, hypotonia, tumor risk }\end{array}$ \\
\hline \multicolumn{3}{|c|}{ Postnatal growth failure (short stature) } \\
\hline Kabuki & $\begin{array}{l}\text { KMT2D (12q13), } \\
\quad K D M 6 A(\mathrm{Xp} 11.3)\end{array}$ & $\begin{array}{l}\text { Arched eyebrows, long eyelashes, developmental } \\
\text { delay, fetal finger pads, scoliosis, heart defects, } \\
\text { hypotonia }\end{array}$ \\
\hline Costello & HRAS (11p15) & $\begin{array}{l}\text { Deep palmar/plantar creases, developmental delay } \\
\text { coarse facial features, heart abnormalities, } \\
\text { papillomas, tumor risk }\end{array}$ \\
\hline \multicolumn{3}{|l|}{ Chromosomal abnormality } \\
\hline Mosaic Turner & (Loss of $X$ in some cells) & $\begin{array}{l}\text { Milder Turner syndrome phenotype (short stature, } \\
\text { coarctation of aorta, gonadal dysgenesis) }\end{array}$ \\
\hline Patau & Trisomy 13 & $\begin{array}{l}\text { Developmental delay, microphthalmia, heart } \\
\& \text { neural defects }\end{array}$ \\
\hline \multicolumn{3}{|l|}{$\begin{array}{l}\text { Congenital disorders } \\
\text { of glycosylation }\end{array}$} \\
\hline Types $1 \mathrm{a}, 1 \mathrm{~b}$, and $1 \mathrm{~d}$ & $\begin{array}{l}P M M 2(16 \mathrm{p} 13.2) \\
\quad M P I(15 \mathrm{q} 24.1) \\
\quad A L G 3(3 \mathrm{q} 27.1)\end{array}$ & Developmental delay, hypotonia, growth failure \\
\hline \multicolumn{3}{|c|}{ Contiguous gene deletion affecting the $A B C C 8$ gene } \\
\hline Usher & 11 genes & Hearing loss, visual impairment \\
\hline \multicolumn{3}{|c|}{ Abnormalities in calcium homoeostasis } \\
\hline Timothy & CACNAIC (12p13.33) & $\begin{array}{l}\text { Long QT syndrome, syndactyly, } \\
\text { developmental delay, immune deficiency }\end{array}$ \\
\hline \multicolumn{3}{|l|}{ Insulin receptor mutation: } \\
\hline $\begin{array}{l}\text { Insulin resistance } \\
\text { syndrome } \\
\text { (leprechaunism) } \\
\text { Other Syndromes: }\end{array}$ & INS (19p13) & $\begin{array}{l}\text { Hypo- and hyperglycemia, pre- and postnatal } \\
\text { growth restriction, elfin-like features, hirsutism }\end{array}$ \\
\hline $\begin{array}{l}\text { Congenital central } \\
\text { hypoventilation } \\
\text { syndrome }\end{array}$ & PHOX2B (4p13) & $\begin{array}{l}\text { Central hypoventilation, "box-shaped" face, } \\
\text { neurocristopathies } \\
\text { (Hirschsprung disease, tumor risk) }\end{array}$ \\
\hline
\end{tabular}

inherited in an autosomal recessive manner whereas the F$\mathrm{CHH}$ is sporadic $[22,72]$.

\subsection{Focal form of CHH (F-CHH)}

Focal lesions occur when the abnormal pancreatic $\beta$ cells are localized to a single specific location in the pancreas. They are the result of two unique events, first the inheritance of a paternally inherited $A B C C 8$ or $K C N J 11$ mutation at $11 \mathrm{p} 15.1$, and secondly the loss of the corresponding maternal allele within the focal lesion. This causes an imbalance in the expression of imprinted genes such as the maternally expressed tumor suppressor gene $H 19$ and $C D K N 1 C$, and the paternally expressed growth factor $I G F-2$, at $11 \mathrm{p} 15.5$ [73] leading to $\beta$-cell hyperplasia. Within the focal islet cell lesion there is adenomatous hyperplasia and abnormally large nuclei in the affected cells.

A duplication of the paternal allele located on chromosome 11 has also been found in some patients with F-CHH [74]. Outside the lesion, normal endocrine tissue with small nuclei exists. These cells appear to have less cytoplasm and diminished proinsulin production [75-78]. 
Fig. 2 Diffuse and focal form of HH with 18F-DOPA-PET-CT images. A - Diagrammatic representation of diffuse form of $\mathrm{CHH}$ and $\mathrm{B}-18 \mathrm{~F}-\mathrm{DOPA}-\mathrm{PET}$ image of diffuse form of CHH. C Diagrammatic representation of focal form of $\mathrm{CHH}$ (showing different types of focal lesions) and D - 18F-DOPA-PET-CT image of focal lesion in the head of pancreas. SUV - Standardized uptake value.

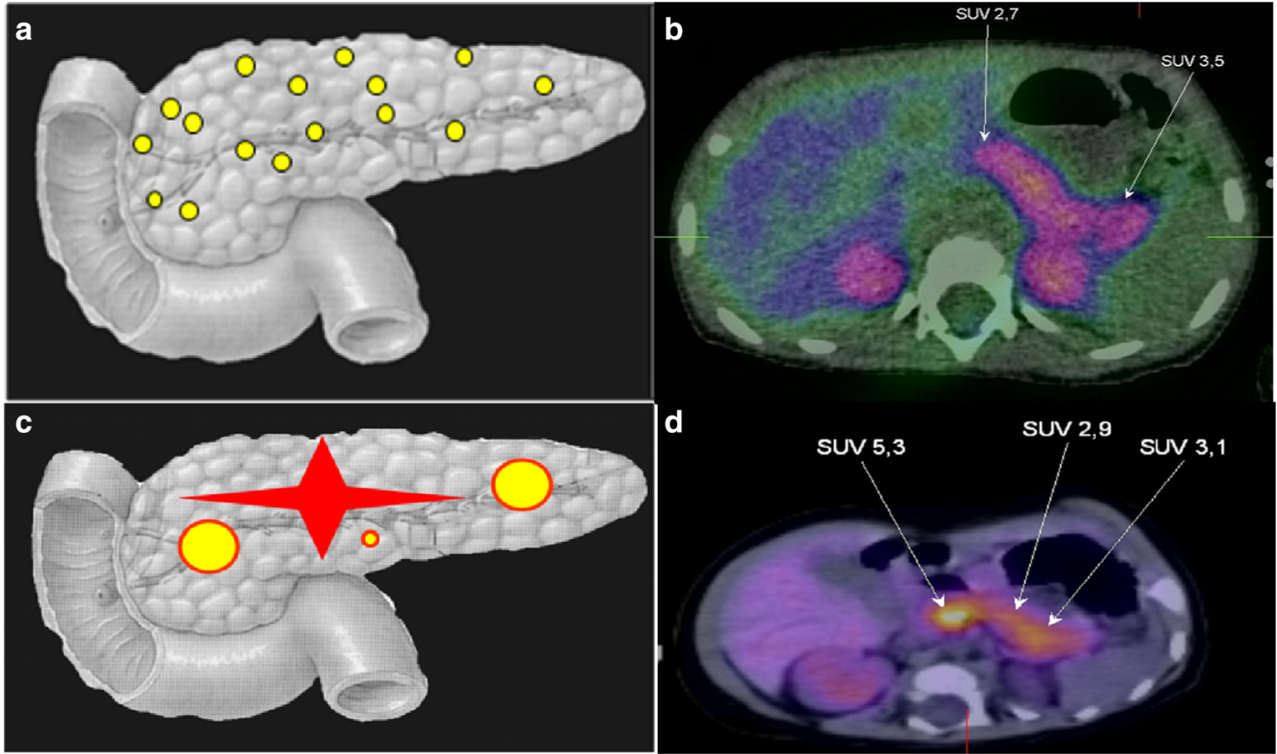

Patients who have a heterozygous paternally inherited mutation in $A B C C 8$ or $K C N J 11$ could have F-CHH, which accounts for $30-40 \%$ of all $\mathrm{CHH}$ cases [79]. F-CHH is confirmed by a fluorine-18 dihydroxyphenylalanine-positron emission tomography (18F-DOPA-PET) scan, which can show the presence of a focal lesion and determine its location with diagnostic accuracy [80].

\subsection{Diffuse form of CHH (D-CHH)}

The D-CHH form occurs when all the islet cells in the pancreas are abnormal $[77,81]$. Patients with a homozygous recessive or a compound heterozygote mutation in $A B C C 8$ or KCNJ11 present with D-CHH. These patients are usually medically unresponsive, and this histological form accounts for $60-70 \%$ of all $\mathrm{CHH}$ cases. Most islets throughout the entire pancreas are affected with the presence of large hyperchromatic nuclei $[75-78,81]$.

\subsection{Atypical forms of $\mathrm{HH}$}

Histologically atypical forms of $\mathrm{CHH}$ are categorized when the pancreatic morphology does not fit into the F-CHH or D$\mathrm{CHH}$ types and are a mosaic pattern of the two [73, 82]. The islets can either be enlarged or shrunken. Some cases have been cured with a lesionectomy whilst others also require medical management. However, to date only one patient has been described with a $A B C C 8$ nonsense mutation (Q54X) causing this histological form of $\mathrm{CHH}$ [82]. Studies have shown that the heterogeneous expression of $\beta$-cells HK1 in the atypical $\mathrm{CHH}$ may be causing the abnormal insulin release $[83,84]$.

\section{Clinical presentation of $\mathrm{HH}$}

HH usually manifests in infancy or early childhood, although some patients can present during adolescence or adulthood. Signs and symptoms of hypoglycemia are non-specific during the neonatal period (poor feeding, jitteriness, irritability), challenging its diagnosis. At later ages, symptoms can be easier to recognize and can be classified as adrenergic (hunger, pallor, tachycardia, tremor, diaphoresis) and neuroglycopenic (tiredness, blurred vision, confusion, coma and even death).

Risk factors for $\mathrm{HH}$ need to be looked for in the perinatal history. These include maternal intrapartum administration of hypoglycemic agents, stressful delivery, large/low birth weight, and neonatal polycythemia or jaundice, among others. Examination of the baby will search for macrosomia/leanness, careful phenotypic characterization to identify syndromes, features of cardiomyopathy (due to glycogen storage in $\mathrm{HH}$ ), hepatomegaly present in metabolic conditions (also present in $\mathrm{HH}$ ), and midline abnormalities (including genitalia) to exclude hypothalamic-pituitary deficits. Data in the family history could suggest a genetic inheritance, therefore anamnesis must enquire for consanguinity, cases of diabetes mellitus, hypoglycemia, seizures and unexplained deaths [85].

\section{Diagnostic investigations of $\mathrm{HH}$}

Any child requiring intravenous glucose load greater than $8 \mathrm{mg} / \mathrm{kg} / \mathrm{min}$ (normal requirement is $4-6 \mathrm{mg} / \mathrm{kg} / \mathrm{min}$ ) to avoid hypoglycemia, can essentially be labeled as HH [86]. The timing of hypoglycemic events with regard to meals will give insight into the intrinsic mechanism. HH typically manifests during brief periods of fasting, however certain types can be manifest soon after meal ingestion (protein induced $\mathrm{HH}$ ) or 
hours after meal ingestion (postprandial HH). Should there be a clear link between physical activity and occurrence of hypoglycemia, then exercise induced HH should be excluded.

\subsection{Biochemistry}

Biochemical interpretation will only be possible if the critical sample is taken adequately at the time of hypoglycemia ( $\leq 3.0 \mathrm{mmol} / \mathrm{l})$, ideally in a controlled fasting setting. HH will demonstrate detectable C-peptide or insulin in the face of hypoglycemia, with simultaneously low/undetectable alternative substrates (ketones and fatty acids) [86, 87]. Of note, the concentration of insulin does not parallel the degree of severity of the condition $[88,89]$. Table 3 defines the diagnostic criteria for $\mathrm{HH}$. If a particular mechanism is suspected to trigger $\mathrm{HH}$ (exercise, protein, carbohydrate etc) specific stimulation tests will be carried out:

\subsubsection{Protein load test}

In this test leucine or a combination of aminoacids is administered enterally. Evidence of raised insulin concentrations at the time of hypoglycemia will confirm the clinical suspicion of protein sensitive $\mathrm{HH}$ [29].

\subsubsection{Oral glucose tolerance test / mixed meal test}

Enteral administration of a mixed meal or oral glucose load followed by hypoglycemia with a detectable insulin within 2$5 \mathrm{~h}$, indicates incretin mediation leading to postprandial $\mathrm{HH}$. In adults the prefered test is the standardized hyperglucidic breakfast [91], which has not yet been standardized in children.

\subsubsection{Exercise test and pyruvate load}

Biochemical evidence of $\mathrm{HH}$ during these tests indicate a lactate/pyruvate mechanism triggering exercise induced $\mathrm{HH}$ [92].

\subsubsection{Fructose load test}

Individuals with ketotic hypoglycemia after fructose ingestion should undertake a fructose load test to identify hereditary fructose intolerance and fructose-1,6-diphosphatase deficiency, and this can be followed by genetic testing.

\subsubsection{The role of real-time continuous glucose monitoring (CGM)}

CGM measures interstitial glucose concentrations indicating the direction, magnitude, frequency, duration and causes of fluctuations in these. There is now a study on its accuracy in children with $\mathrm{HH}$ [93], as this can significantly improve the quality of life of these patients.

\subsection{Imaging}

\subsubsection{Recent advances in diagnostic imaging of $\mathrm{HH}$}

As is not possible to differentiate between F-CHH and D$\mathrm{CHH}$ based on clinical presentation and biochemical features,
Table 3 Diagnostic criteria for $\mathrm{HH}$ - The cut-off values for each analyte to aid in the diagnosis of HH. IGFBP-1: Insulin growth factor binding protein-1. HI/HA: Hyperinsulinemic hypoglycemia hyperammonemia syndrome. HADH: short chain L-3hydroxyacil-CoA dehydrogenase. Im: intramuscular. Iv: intravenous. Sc: subcutaneous $*[90,200$, 203]

\begin{tabular}{|c|c|}
\hline Serum analyte & Result in patients with $\mathrm{HH}$ \\
\hline \multicolumn{2}{|c|}{ Blood glucose $<3.0 \mathrm{mmol} / 1(54 \mathrm{mg} / \mathrm{dl})$ and: } \\
\hline Insulin & Detectable \\
\hline C-peptide & Detectable $\left(\geq 0.5 \mathrm{ng} / \mathrm{mL}^{¥}\right)$ \\
\hline Free fatty acids & Low or suppressed $\left(<1.5 \mathrm{mmol} / /^{*}\right.$ or $\left.<1.7 \mathrm{mmol} / /^{¥}\right)$ \\
\hline Ketone bodies & Low or suppressed $\left(3-\beta\right.$-hydroxybutyrate $<2 \mathrm{mmol} / \mathrm{l}^{*}$ or $\left.<1.8 \mathrm{mmol} / \mathrm{l}^{¥}\right)$ \\
\hline IGFBP-1 & Low $\left(\leq 110 \mathrm{ng} / \mathrm{mL}^{¥}\right)$ as insulin negatively regulates IGFBP-1 expression \\
\hline Ammonia & Normal. Can be raised in HI/HA syndrome \\
\hline Hydroxybutyrylcarnitine & Normal. Raised in $\mathrm{HH}$ due to $H A D H$ mutation \\
\hline $\begin{array}{l}\text { Cortisol, Growth } \\
\text { hormone }\end{array}$ & $\begin{array}{l}\text { Raised. Generally Cortisol }>20 \mu \mathrm{g} / \mathrm{dL}[500 \mathrm{nmol} / \mathrm{L}] \text {; growth hormone } \\
>7 \mathrm{ng} / \mathrm{mL} \text { - younger children might have poor counter-regulatory response }\end{array}$ \\
\hline $\begin{array}{l}\text { Amino acids and urine } \\
\text { organic acids }\end{array}$ & Normal. Leucine, isoleucine and valine may be suppressed in $\mathrm{HH}$ \\
\hline Proinsulin & $>20 \mathrm{pmol} / 1$ \\
\hline \multicolumn{2}{|c|}{ Additional information when diagnosis of $\mathrm{HH}$ uncertain: } \\
\hline Glucose infusion rate & $>8 \mathrm{mg} / \mathrm{kg} / \mathrm{min}$ to achieve euglycemia \\
\hline $\begin{array}{l}\text { Im or iv glucagon } \\
\text { administration or }\end{array}$ & $>1.5 \mathrm{mmol} / \mathrm{L}$ or $27 \mathrm{mg} / \mathrm{dl}$ (Positive glycemic response) \\
\hline
\end{tabular}


pre-operative differentiation of both subtypes is critically important. Conventional radiological imaging such as Magnetic Resonance Imaging (MRI) and Computerized Tomography (CT) scans fail to localize the focal lesions. Genetic analysis for mutations in $A B C C 8 / K C N J 11$, with combination of recently described Fluorine 18 L-3, 4- dihydroxyphenyalanine positron emission tomography (18F-DOPA-PET-CT) scanning, allows differentiation between $\mathrm{F}-\mathrm{CHH}$ and D-CHH with a high sensitivity (88\%) and specificity (94\%) [94-98], with an accuracy of $100 \%$ [99-102]. The principle of $18 \mathrm{~F}-$ DOPA-PET analysis is based on the selective uptake of LDOPA by $\beta$-cells and its conversion into dopamine by DOPA decarboxylase enzyme, which is expressed in the pancreatic $\beta$-cells. Thus, imaging with $18 \mathrm{~F}$-DOPA-PET-CT should be performed in all patients who are thought to have F-CHH. Some patients have been described with atypical histological forms, which are either atypical focal, atypical diffuse or ectopic $\beta$-cell hyperplasia and do not show classical features of F-CHH or D-CHH [103]. Demonstration of increased activity of DOPA decarboxylase by $18 \mathrm{~F}-\mathrm{DOPA}-\mathrm{PET}$ in combination with an enhanced CT imaging can successfully differentiate diffuse and focal $\beta$-cell hyperplasia. Therefore, this technique has radically changed the surgical approach to patients with medically unresponsive HH $[102,104]$.

A dosimetry study of 18F-DOPA derived from the PET-CT images in ten infants (median age 4.84 weeks) with HH suggested that a modest radiation dose $(0.30 \pm 0.04 \mathrm{mSv} / \mathrm{MBq})$ was adequate [105]. However, there have been recent reports of its inaccuracy in precisely detecting focal lesions [106, 107]. Glucagon-like-peptide-1 (GLP-1) receptor analogs are the latest agents being used in the detection of insulinomas in adults [108, 109]. Similarly, this isotope is being investigated in children to detect focal lesions.

\subsubsection{Imaging for insulinoma}

Most insulinomas are benign (islet-cell tumors) and usually very small $(<2 \mathrm{~cm})$ making it difficult to localize with the current imaging techniques. Various non-invasive techniques have been used for the detection of insulinomas e.g., transabdominal ultrasonography, spiral CT, MRI, ${ }^{111} \mathrm{In}$ pentetreotide imaging, and ${ }^{18} \mathrm{~F}$-1-dihydroxyphenylalanine PET. In difficult cases, invasive procedures like endoscopic ultrasonography or selective arterial calcium stimulation test with hepatic venous sampling have also been used [110].

A systematic review and meta-analysis of $(68) \mathrm{Ga}$ DOTATATE compared with octreotide and conventional imaging documented a high sensitivity $(90.9 \%)$ and specificity $(90.6 \%)$ of (68)Ga-DOTATATE in detecting neuroendocrine tumors [111]. Various Gallium based isotopes have also been used to detect insulinoma in adults [108, 112].

\section{Management of $\mathrm{HH}$}

Maintaining normoglycemia (blood glucose $>3.5 \mathrm{mmol} / \mathrm{l}$ ) is paramount to avoid hypoglycemic brain injury in view of the hypoketotic nature of HH [113]. This may be achieved by increasing glucose administration (feeds or intravenous (iv) fluids), stimulating endogenous glucose release (glucagon administration) or suppressing insulin release from the $\beta$-cell (diazoxide, octreotide, nifedipine). Oral feeds with additional glucose polymer in combination with iv fluids can also be used to maintain normoglycemia. The traditional and new drugs available for the management of $\mathrm{HH}$ are summarized in Table 4.

\section{Current medical management}

\subsection{Acute management of hypoglycemia}

If the oral route is unavailable or glycemia is not improving despite oral glucose (glucose gel/glucose containing drinks or tablets), then an iv dextrose bolus ( $2 \mathrm{ml} / \mathrm{kg} 10 \%$ Glucose) needs to be administered followed by continuous iv glucose infusion ( $>8 \mathrm{mg} / \mathrm{kg} / \mathrm{min}$ ). If there is persistence of hypoglycemia, hypoglycemic seizure or inadequate iv access, then an intramuscular or subcutaneous bolus $(1 \mathrm{mg})$ or infusion of glucagon can be life saving as it causes immediate release of glycogen stores from the liver leading to a temporary improvement in blood glucose concentrations. [117].

As high iv glucose concentration is usually needed for weeks, insertion of a central venous access supports in managing glycemia safely.

\subsection{Long-term pharmacological agents}

Medical therapies can be tried to wean the infant off iv support and achieve a near-normal feeding pattern. Surgical therapy is considered when trial of medical therapies is unsuccessful or in case of established F-CHH.

$\mathrm{HH}$ drug responsiveness is defined by: 1) normal feeding frequency and volume, 2) fasting capability adequate for age whilst maintaining euglycemia, 3) low/suppressed serum insulin level at the end of the fast, and 4) appropriate generation of ketone bodies and fatty acids by the end of the fast [117].

Diazoxide The first drug of choice is diazoxide [86], which requires a functional $\mathrm{K}_{\mathrm{ATP}}$ channel to bind onto and is hence ineffective in D-CHH due to an inactivating $\mathrm{K}_{\mathrm{ATP}}$ mutation and in most cases of F-CHH. Most other forms of $\mathrm{HH}$ and protracted HH secondary to risk factors such as IUGR and perinatal asphyxia respond to treatment with diazoxide. Due to its fluid retaining properties, diazoxide therapy must be used with caution in infants with $\mathrm{HH}$ who are often receiving 
Table 4 Standard and novel drugs used in the management of HH - Medications used for the treatment of HH, along with their dose, mechanism of action and side effects $[114-116,134,140,201]$

\begin{tabular}{|c|c|c|c|c|}
\hline \multicolumn{2}{|c|}{$\begin{array}{l}\text { Medication } \\
\text { (route of administration) }\end{array}$} & \multirow{2}{*}{$\begin{array}{l}\text { Total daily dose } \\
5-20 \mathrm{mg} / \mathrm{kg} / \text { day } \\
\text { (divided in } 3 \text { doses) }\end{array}$} & \multirow{2}{*}{$\begin{array}{l}\text { Action mechanism } \\
\text { Binds to the SUR1 subunit of intact } \\
\text { KATP channels, opening the } \\
\text { channel and inhibiting insulin } \\
\text { release }\end{array}$} & \multirow{2}{*}{$\begin{array}{l}\text { Side effects } \\
\text { Common: Fluid and sodium retention, } \\
\text { hypertrichosis, anorexia. } \\
\text { Rare: Cardiac failure, pulmonary } \\
\text { hypertension**, blood dyscrasia, } \\
\text { hyperuricemia, paradoxical } \\
\text { hypoglycemia }\end{array}$} \\
\hline Standard drugs & $\begin{array}{l}\text { Diazoxide } \\
\text { (enteral) }\end{array}$ & & & \\
\hline & $\begin{array}{l}\text { Chlorothiazide } \\
\text { (enteral) }\end{array}$ & $\begin{array}{l}\text { 7-10 mg/kg/day } \\
\text { (divided in } 2 \text { doses) }\end{array}$ & $\begin{array}{l}\text { Synergy with diazoxide over KATP } \\
\text { channels inhibiting insulin } \\
\text { secretion. Prevents fluid overload }\end{array}$ & Hyponatremia, hypokalemia \\
\hline & $\begin{array}{l}\text { Glucagon } \\
\text { (sc/im bolus; } \\
\text { sc/iv infusion) }\end{array}$ & $\begin{array}{l}\text { Bolus: } 0.02 \mathrm{mg} / \mathrm{kg} / \mathrm{dose} \\
\text { Infusion: } 2.5-10 \mathrm{mcg} / \mathrm{kg} / \mathrm{h}\end{array}$ & $\begin{array}{l}\text { Stimulates glycogenolysis, } \\
\text { gluconeogenesis, ketogenesis, } \\
\text { lipolysis }\end{array}$ & $\begin{array}{l}\text { Skin rash, vomiting. Paradoxical } \\
\text { rebound hipoglycemia if dose } \\
>20 \mathrm{mcg} / \mathrm{kg} / \mathrm{h} \text { (high dose stimulates } \\
\text { insulin release) }\end{array}$ \\
\hline & $\begin{array}{l}\text { Octreotide } \\
(s c)\end{array}$ & $\begin{array}{l}\text { 5-40 mcg/kg/day } \\
\text { (divided in 3-4 doses } \\
\text { or continuous infusion) }\end{array}$ & $\begin{array}{l}\text { Activation of SSTR-2 and SSTR-5. } \\
\text { Stabilisation of } \mathrm{K}_{\text {ATP }} \text { channel, re- } \\
\text { duces calcium entry in } \beta \text {-cell, in- } \\
\text { hibition of insulin secretion. } \\
\text { Inhibitition of INS promoter. }\end{array}$ & $\begin{array}{l}\text { Acute: Abdominal discomfort, } \\
\text { vomiting, diarrhea, anorexia, } \\
\text { hepatitis, transaminasemia, long QT } \\
\text { syndrome, necrotizing enterocolitis, } \\
\text { tachyphylaxis. } \\
\text { Long-term: Cholelithiasis, intestinal } \\
\text { hypomobility, suppression of GH } \\
\text { and TSH }\end{array}$ \\
\hline & $\begin{array}{r}\text { Nifedipine } \\
\text { (enteral) }\end{array}$ & $\begin{array}{l}0.25-2.5 \mathrm{mg} / \mathrm{kg} / \mathrm{day} \\
\quad \text { (divided in } 2-3 \text { doses) }\end{array}$ & $\begin{array}{l}\text { Blockage of } \beta \text {-cell calcium channel } \\
\text { activity, leading to inhibition of } \\
\text { insulin exocytosis }\end{array}$ & Hypotension \\
\hline & Acarbose (enteral) & $\begin{array}{l}6.25-300 \mathrm{mg} / \text { day (divided } \\
\text { in } 3 \text { doses - before main } \\
\text { meals) }\end{array}$ & $\begin{array}{l}\text { Inhibits intestinal } \alpha \text {-glucosidase } \\
\text { (cleaves polysaccharides to } \\
\text { monosaccharides) }\end{array}$ & $\begin{array}{l}\text { Intestinal discomfort, diarrhoea, } \\
\text { flatulence, raised transaminases }\end{array}$ \\
\hline \multirow[t]{2}{*}{ Novel drugs } & $\begin{array}{l}\text { Lanreotide and } \\
\text { long-acting } \\
\text { octreotide } \\
\text { (deep sc or im) }\end{array}$ & $\begin{array}{l}30-60(\max 120 *) \mathrm{mg} / \text { dose } \\
\text { (every } 4 \text { weeks) }\end{array}$ & $\begin{array}{l}\text { Like octreotide. High affinity for } \\
\text { SSTR } 2 \& 5 \text {, and reduced affinity } \\
\text { for SSTR } 1,3 \& 4\end{array}$ & $\begin{array}{l}\text { Same as octreotide. Pain at injection } \\
\text { site. No long-term data available yet. }\end{array}$ \\
\hline & $\begin{array}{l}\text { mTOR inhibitors } \\
\text { (enteral) }\end{array}$ & $\begin{array}{l}\text { Starting dose: } 1 \mathrm{mg} / \mathrm{m}^{2} / \text { day } \\
\text { (divided in } 2 \text { doses). } \\
\text { Adjust dose aiming for } \\
\text { blood concentrations } \\
5-15 \mathrm{ng} / \mathrm{ml}\end{array}$ & $\begin{array}{l}\text { Inhibits mTOR complex 1. Inhibits } \\
\beta \text {-cell proliferation and insulin } \\
\text { secretion. Posible induction of } \\
\text { peripheral insulin resistance }\end{array}$ & $\begin{array}{l}\text { Immune suppression, hyperlipidemia, } \\
\text { hypertransaminasemia, mucositis, } \\
\text { thrombocytosis }\end{array}$ \\
\hline
\end{tabular}

Sc: subcutaneous. Im: intramuscular. Iv: intravenous. SSTR: Somatostatin receptor. INS: insulin gene. SUR1 = sulfonylurea receptor 1 . KATP = ATPsensitive potassium channel.

$* *[115,116]$

*90-120 mg every 4 weeks [134]. The starting dose of Lanreotide autogel $30 \mathrm{mg}$ has been found to be effective [132, 133]

large volumes of iv/oral fluids to maintain normoglycemia. Fluid restriction prior to starting diazoxide is commonly practiced, along with concomitant use of a thiazide diuretic such as chlorothiazide, which also has a synergistic action over the $\mathrm{K}_{\text {ATP }}$ channels.

\subsubsection{Medical management of diazoxide unresponsive D-CHH}

Nifedipine Authors suggest triyng it before heading to pancreatectomy [118] as there have been isolated case reports on successful treatment of HH with nifedipine [119-121] but experience of large $\mathrm{HH}$ centers has generally been disappointing $[117,122,123]$. It is sometimes considered as an add-on drug in partial diazoxide/octreotide resistance, and/or following partial pancreatectomy $[122,124]$ but rarely used as monotherapy.

Octreotide Octreotide is a second-line treatment for diazoxide-insensitive patients $[125,126]$. It may be used in combination with diazoxide and glucagon in cases with partial diazoxide response, or often combined with frequent feeding which may require a gastrostomy to enable high calorie bolus feeding during the day and overnight continuous feeds. As octreotide binds to the somatostatin receptors SSTR-2 and SSTR-5, prolonged use may develop into drug desensitizing caused by internalisation of the receptors [122]. 
Glucagon Iv or subcutaneous (sc) glucagon [127] may be helpful during the initial stabilization period and before surgery. However, this treatment has not been of long-term benefit. It can also be administered (alone or in combination with Octreotide) to stabilize blood glucose concentrations in the acute management and prevent near-total pancreatectomy in infants with HH [128]. Continuous sc glucagon infusion can frequently complicate by catheter obstructions occurring daily or 2-3 times per week [128].

Acarbose For postprandial HH the first approach is diet modification. This includes: frequent feeds of long-acting carbohydrates, abundant protein and supplements of fibre and fat emulsions [129]. If hypoglycemia persists, acarbose is the preferred medical option as it slows the absorption of glucose into the blood stream, thus avoiding a glycemic peak followed by insulin release [130].

\section{Novel medical therapies}

\subsection{Long-acting somatostatin analogues}

Lanreotide and Long-acting release octreotide (LAROctreotide) are two formulations used in few numbers of patients with HH [131-136] reported not only to be useful in the management of $\mathrm{HH}$ in children, but potentially displaying a more stable glycemic control than octreotide [134]. Lanreotide has also been proven useful in managing inoperable F-CHH [137].

\section{2 mTOR inhibitors}

The intracellular mTOR pathway is involved in $\beta$-cell growth and altered insulin secretion in patients with insulinoma [138]. Therefore, mTOR inhibitors such as sirolimus (formerly known as rapamycin) and everolimus have been used to treat this tumor. Although the exact mechanism of sirolimus in $\mathrm{HH}$ still needs to be elucidated, it has been hypothesized that the mTOR complex 1 may be overactivated in D-CHH [139]. The first study reported the use of sirolimus in 4 children with severe D-CHH who achieved glycemic control avoiding pancreatectomy and with no major side effects [140]. This has been followed by various case reports of $\mathrm{HH}$ in children of various ages who have benefitted from sirolimus [141-145]. However, there have been reports about its severe side effects as well as poor response in others [146-149]. Our center has tried sirolimus on 22 patients with various forms of $\mathrm{HH}$, out of which 21 showed glycemic response, however 19 patients developed side effects, recurrent and frequent infections being the most common infections [150]. There is no clear correlation between genetic etiology and response to sirolimus.

\section{Potential novel therapies - The future}

\subsection{GLP-1 antagonists}

GLP- 1 acts on the $\beta$-cell promoting its proliferation and stimulating insulin release [151]. Mouse models with $\mathrm{K}_{\mathrm{ATP}}$ channel defects leading to $\mathrm{HH}$, significantly improved their glucose concentrations when treated with GLP-1 receptor antagonist (exendin-9-39) [152]. Infusion of exendin-9-39 has been tried in 9 adult patients with $\mathrm{HH}$ due to $\mathrm{K}_{\text {ATP }}$ mutations [153], where all patients demonstrated increased fasting mean glucose and glucose area under the curve, raising expectation for its near-future use in children with this condition.

\subsection{Pharmacological trafficking chaperones}

Some mutations in the $A B C C 8$ gene prevent trafficking of parts of the SUR1 channel from the endoplasmic reticulum to the surface of the cell. Carbamazepine [154] and sulfonylureas [155] - glibenclamide and tolbutamide - are $\mathrm{K}_{\mathrm{ATP}}$ channel inhibitors and chaperones that have proven to amend channel trafficking defects in many $A B C C 8$ mutations by allowing intersubunit interactions between SUR1 and Kir6.2 [156]. This has been now confirmed in mouse functional studies as well [157] reinforcing its potential for clinical use.

\subsection{Glucagon - New formulations and delivery}

Subcutaneous glucagon infusion via pump has been used as long-term treatment for HH patients at home [158]. Practical issues with its administration remain unsolved as it can cause mechanical obstruction due to its formulation. However, a stable form of glucagon formulation could be a potential useful tool that is being explored $[159,160]$.

\section{Surgical management}

\subsection{Surgery for F-CHH}

Removal of the affected part of the pancreas achieving complete cure is the surgical aim for the F-CHH. A multidisciplinary team (endocrinology, radiology, and histopathology) should be involved in managing patients with $\mathrm{F}-\mathrm{CHH}$ and D-CHH [161, 162]. In most cases, pre-operative 18F-DOPA PET-CT helps exact localization of the focal lesion and aids the surgeon. Intra-operative biopsies are important to ensure complete excision with histological confirmation of clear margins. Laparoscopic lesionectomy is the preferred surgical approach when the focal lesion is easily accessible (i.e. body or tail of pancreas) offering the benefit of shorter post-operative care [163]. Focal lesions that are difficult to access such as in the head of the pancreas usually require open laparotomy for 
resection of most of the pancreatic head and Roux-en-Y pancreaticojejunostomy [164].

\subsection{Surgery for D-CHH}

Near-total pancreatectomy (95-98\% of the pancreas), the only option for medically unresponsive D-CHH has largely been reported to have unsatisfactory outcomes $[165,166]$. In a large study, nearly $59 \%$ of patients that underwent near total pancreatectomy continued to experience hypoglycemia, though it was usually easier to manage with dietetic/medical therapy. Post-operatively, hyperglycemia was common as well with increasing incidence as age progressed and a $100 \%$ incidence by 13 years of age [166]. Complex glucose derangements with persisting fasting hypoglycemia and post-prandial hyperglycemia were also reported in 35\% of patients. Exocrine pancreatic insufficiency is also common following near-total pancreatectomy for D-CHH [166]. Laparoscopic surgery is now the preferred option as opposed to the traditional open approach $[161,167]$.

\subsection{Surgery for insulinoma}

Surgical removal of the tumor is the mainstay therapy for childhood and adult insulinoma, and its overall cure rate is up to $98 \%[168,169]$. Prognosis depends on the tumor stage at the time of presentation and success rate of complete resection. The mode of surgery depends on the tumor size, localization, and metastatic characteristics $[69,170]$. For small benign tumors with no metastasis that are located at least 2$3 \mathrm{~mm}$ from the main pancreatic duct, a limited enucleation should be performed [171]. A tumor that is invading the pancreatic duct or great vessels with risk of malignancy and lymph node invasion, and that is compressing the distal pancreatic duct, might require a more extensive surgical resection. The surgical resection procedure depends on the site of the insulinoma and includes mid-body pancreatectomy, distal pancreatectomy, or pylorus-preserving Whipple procedure $[171,172]$.

\section{$13 \mathrm{HH}$ monitoring and follow up}

Children with $\mathrm{HH}$ need regular monitoring of their blood glucose at home. The follow-up of these children requires involvement of a multidisciplinary team including pediatric endocrinologist, dietitian, nurse specialist, clinical psychologist, developmental pediatrician and pediatric surgeon. Severity and treatment requirement should be assessed periodically in all children on medical therapy and the dose of medications should be optimized based on their glucose monitoring and fast tolerance test. It has been reported that for most patients with $\mathrm{K}_{\mathrm{ATP}}$ channel mutations who are managed by medical treatment only, severity is reduced over time [173]. Children need to be monitored for the side effects of the HH medications [135, 146, 147, 174, 175]. Also, the majority of children with severe $\mathrm{HH}$ are on high carbohydrate feeds administered via gastrostomy by bolus and/or continuous feeds, hence the importance in receiving support from the community i.e. nursery, school, home etc. in these group of children. Post-surgical patients require periodical monitoring including stool elastase, capillary glucose measurements and oral glucose tolerance test looking for complications (hypoglycemia, diabetes and exocrine pancreatic insufficiency) $[165,166]$. Various studies evaluating the long-term outcome of patients with $\mathrm{HH}$ have reported a high frequency of neurodevelopment delay and various neurological disorders, including epilepsy and microcephaly $[5,176,177]$. This group of children may need a special education plan devised with the help of the educational psychologist and developmental pediatrician.

\section{Transition into adult service}

Young adults with HH have complex management requirements that are best supported using a multidisciplinary approach [178]. The move from pediatric to adult services may be a challenging time for adolescents transitioning to selfmanagement [179].

A transition service aims to bridge this changeover in care, and support the adolescent [180] in terms of their health needs, but also psychosocial development, including ability to achieve independence and establish adult relationships [181, 182]. This specific age group are recognized to have barriers that prevent optimal self-management, including [183];

- heightened concerns about peer relationships and social interactions,

- frustration and fatigue from the management of a chronic illness,

- incomplete knowledge and understanding of chronic disease management,

- inclination towards risk-taking and

- difficulties in the transition to self-management.

People with chronic conditions experience differences in the clinical management approach of pediatric and adult care settings during the transition process [182]. Pediatric teams may overlook the growing independence of the individual, however conversely, the encouragement to take responsibility from adult care providers may lead to physical, psychological and social development being neglected [182, 184, 185].

Consequently, young adults often feel misplaced in adult services and this has been shown to lead to lower rates of follow-up appointments, attendance and medication compliance $[181,186]$. 
Discharge to a non-specialist adult team carries with it some challenges, including lack of awareness about this rare condition and its complex on-going health-needs. In addition, non-specialist teams may not be best placed to undertake discussions around pre-conception counselling in those with a confirmed genetic etiology.

\subsection{Aims of the transition service}

Recognizing the core attributes of this age group, a transition service for patients with $\mathrm{HH}$ may be established, with the following aims and in line with established NICE guidance [178].

1. Supporting education: Establish and support understanding of $\mathrm{HH}$. Where genetic causes are identified, patients should be aware of this and have an understanding of its inheritance.

2. Empowering self-management: To support handover of care to the affected individual from the carers [187], by encouraging shared decision-making and empowering self-management, with an ultimate aim of self-management [188].

3. Addressing parental and care-giver concern [189]: Establishing an understanding between the young person and their carer of how aspects of self-care might be jointly undertaken and transferred is an important component of managing distress, expectations and, ultimately, transition [190].

4. Addressing on-going medical issues: Table 5 summarizes some of the medical issues that may be addressed in a transition service. The risk and progression to diabetes is variable and appropriate treatments for diabetes may depend on both the mutation causing $\mathrm{HH}$ and the extent of $\beta$-cell failure.

5. Dealing with impaired awareness of hypoglycemia [191]: If found in severe cases of HH it can be formally assessed using the validated Clarke [192] or Gold score [193]. The evidence base for managing impaired awareness of hypoglycemia is limited in the context of $\mathrm{HH}$ [194] and so, care is needed in managing these individuals. CGM could be of use in some cases [191].

6. Providing advice around driving: Supporting individuals at high risk of hypoglycemia or impaired awareness of hypoglycemia to apply for a driving license may be explored, and fully explaining driving regulations in relation to hypoglycemia is important for those starting to learn to drive [195].

7. Providing support to higher educational institutions and those in employment [196, 197]: Flexibility may be required to allow time for testing, or additional breaks for calorie consumption.
8. Pre-conception genetic counseling, where appropriate: In those with confirmed dominant mutations, ensuring adequate counseling around offspring, and accessing genetic counselors when appropriate, is important. Insulin modulates Sertoli cell function and young hyperinsulinemic patients have been found to have lower anti-Müllerian hormone and inhibin B secretion [198]. This could therefore influence testicular function and have a future impact on fertility, which still needs to be studied.

9. Continued dietetic advice: On-going advice about dietary management of hypoglycemia, especially where there is protein-induced hypoglycemia, and replacement of calories with other macronutrients may be provided.

10. Alcohol and recreational drug advice [199]: alcohol consumption can potentiate the risk of hypoglycemia and also impair awareness of hypoglycemia. Recreational drugs may also mask the adrenergic symptoms of hypoglycemia.

\subsection{Developing the HH transition pathways}

In line with NICE transition service guidelines [178], the optimal pathway for transitioning individuals with $\mathrm{HH}$ must be developed, summarized in Fig. 3. This includes:

- Planning a service: Young people should be involved in designing the service.

- Planning for transition, which should be appropriately timed for the individual.

- Before Transition: young adults should have joint clinics with the pediatric and adult teams.

\section{Concluding remarks and future directions}

$\mathrm{HH}$ is a challenging condition to treat due to its heterogeneity. Despite diagnostic and therapeutic advances, $\mathrm{HH}$ remains an important cause of morbidity in children, still accounting for 26-44\% of permanent intellectual disabilities, especially in neonatal-onset patients. The increasing use of NGS target panels, combined with clinical, biochemical and imaging findings allows differentiating the diagnostic management of children with $\mathrm{F}-\mathrm{CHH}$, surgically curable, from those with D$\mathrm{CHH}$, more conservatively treated with pharmacological and nutritional interventions [200].

There is now more research of use of CGM in children with $\mathrm{HH}$ which might help to detect early hypoglycemia leading to prompt management [93]. There have been 
Table 5 Summary of medical issues encountered in adolescent and young adult patients with congenital hyperinsulinism and the intervention required.

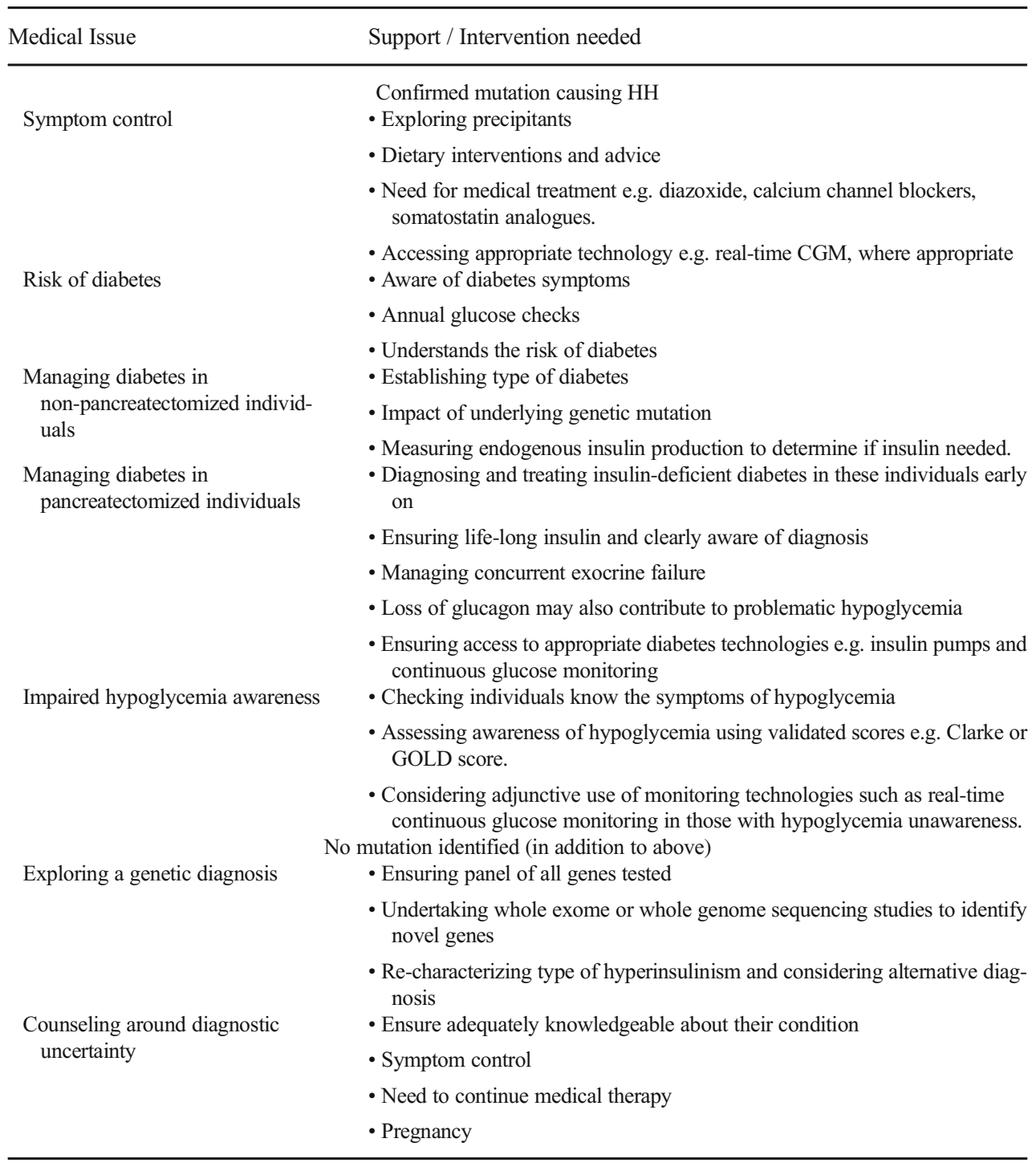

reports of pitfalls of $18 \mathrm{~F}-\mathrm{DOPA}$ PET-CT in accurately detecting focal lesions in $\mathrm{CHH}$ [106, 173]. Glucagonlike-peptide-1 (GLP-1) receptor analogs are the latest agents being used in the detection of insulinomas in adults [108, 109] and are similarly being trialed in children to detect F-CHH.

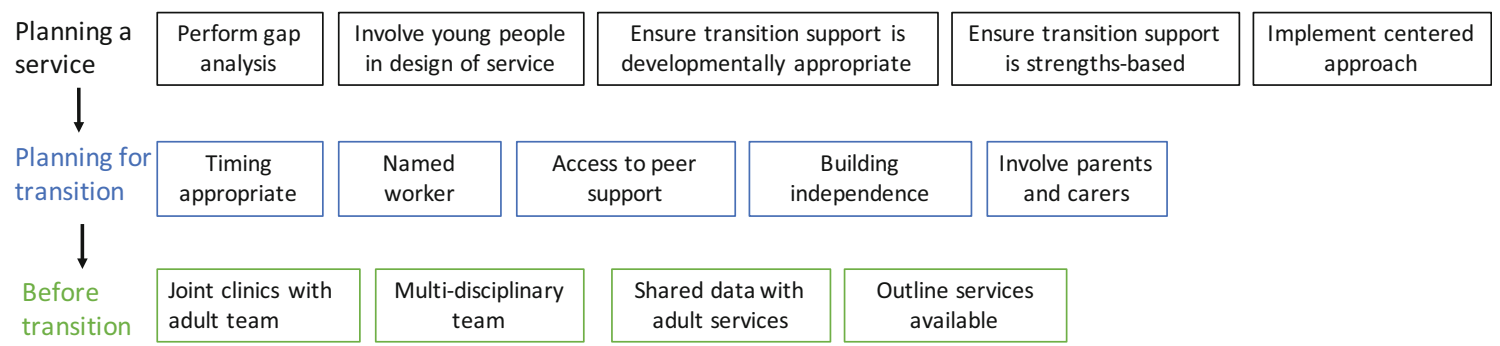

Fig. 3 Flow chart of the stages in planning transition. Various factors should be considered before the young person is actually transitioned to adult services. The timing of transition is critical and should be individualized according to the assessment of the multi-disciplinary team. Box 1 Quotes from patients, carers and other family members on the ideal features of a transition clinic. Seeing older patients in clinic waiting areas who might be in the advanced stages of the same condition is scary.
Understanding that there are other conditions in the same clinic, or that treatments have changed, helps to remove some of the fear. Young people are often used to being told off and will sometimes try to avoid this by simply not going to an appointment if they are running late. Knowing who they can contact can help prevent this. Will we see one of a team or a named Consultant? I'd like to see the same person for the first few appointments so that we can establish a good relationship. 
Over the last few years, numerous medications have been tried in children with HH [201]. For instance long-acting somatostatin analogues and mTOR inhibitors (sirolimus) have been used in various groups of children with varied response [133-136, 140-142, 148]. There is potential use of insulin receptor antagonists as a therapeutic approach to control hypoglycemia in $\mathrm{CHH}[202,203]$. Also, reports have documented the use of a stable form of glucagon in adults with hypoglycemia $[159,160]$, however more clinical trials are required to prove its efficacy in children with $\mathrm{HH}$.

Besides the development of new diagnostic tools and therapeutic agents, clinicians need to become involved in creating/ potentiating $\mathrm{HH}$ transition clinics to provide optimal ongoing care into adulthood for these patients.

Funding information Nick Oliver is supported by the NIHR BRC at Imperial College Healthcare NHS Trust. The views expressed are those of the authors and not necessarily those of the NHS, the NIHR or the Department of Health. The other authors have no funding to declare.

\section{Compliance with ethical standards}

Conflict of interest Nick Oliver has received honoraria for advisory board participation or speaking from Dexcom, Roche diabetes, and Medtronic diabetes; support for education from Novo Nordisk and Takeda; and research funding from Dexcom and Roche diabetes. The other authors have no information to disclose.

Grants and fellowships supporting the writing of the paper Sarah Flanagan is supported by a Sir Henry Dale Fellowship jointly funded by the Wellcome Trust and the Royal Society $(105,636 / Z / 14 / Z)$. The other authors are not supported by grants or fellowships.

Open Access This article is licensed under a Creative Commons Attribution 4.0 International License, which permits use, sharing, adaptation, distribution and reproduction in any medium or format, as long as you give appropriate credit to the original author(s) and the source, provide a link to the Creative Commons licence, and indicate if changes were made. The images or other third party material in this article are included in the article's Creative Commons licence, unless indicated otherwise in a credit line to the material. If material is not included in the article's Creative Commons licence and your intended use is not permitted by statutory regulation or exceeds the permitted use, you will need to obtain permission directly from the copyright holder. To view a copy of this licence, visit http://creativecommons.org/licenses/by/4.0/.

\section{References}

1. Ahrén B. Autonomic regulation of islet hormone secretionimplications for health and disease. Diabetologia. 2000;43(4): 393-410.

2. Senniappan S, Shanti B, James C, Hussain K. Hyperinsulinaemic hypoglycaemia: genetic mechanisms, diagnosis and management. J Inherit Metab Dis. 2012;35(4):589-601.

3. Chinoy, A. et al. 'Focal congenital hyperinsulinism as a cause for sudden infant death'. Pediatr Dev Pathol. 2019;22(1):65-69.
4. Guyot A, Moreau F, Eberhard M, Gaulier JM, Paraf F. Congenital hyperinsulinism revealed by sudden infant death. Ann Pathol. 2017;37(5):429-32.

5. Avatapalle HB, et al. Abnormal neurodevelopmental outcomes are common in children with transient congenital Hyperinsulinism. Front Endocrinol (Lausanne). 2013;4:60.

6. Güemes M, Rahman SA, Hussain K. What is a normal blood glucose? Arch Dis Child. 2016;101:569-574.

7. Thornton PS, Stanley CA, de Leon DD, Harris D, Haymond MW, Hussain K, et al. Recommendations from the pediatric Endocrine Society for evaluation and Management of Persistent Hypoglycemia in neonates, infants, and children. J Pediatr. 2015;167(2):238-45.

8. Hussain K. Diagnosis and management of hyperinsulinaemic hypoglycaemia of infancy. Horm Res. 2008;69(1):2-13.

9. Patel P, Charles L, Corbin J, et al. A unique allosteric insulin receptor monoclonal antibody that prevents hypoglycemia in the SUR-1-/- mouse model of KATP hyperinsulinism. MAbs. 2018;10(5):796-802.

10. Arya VB, Mohammed Z, Blankenstein O, de Lonlay P, Hussain K. Hyperinsulinaemic hypoglycaemia. Horm Metab Res. 2014;46(3):157-70.

11. Vannucci RC, Vannucci SJ. Hypoglycemic brain injury. Semin Neonatol. 2001;6(2):147-55.

12. Hussain K, et al. An activating mutation of AKT2 and human hypoglycemia. Science. 2011;334(6055):474.

13. Staufner C, Lindner M, Dionisi-Vici C, Freisinger P, Dobbelaere D, Douillard C, et al. Adenosine kinase deficiency: expanding the clinical spectrum and evaluating therapeutic options. J Inherit Metab Dis. 2016;39(2):273-83.

14. Gillis D, Krishnamohan A, Yaacov B, Shaag A, Jackman JE, Elpeleg O. TRMT10A dysfunction is associated with abnormalities in glucose homeostasis, short stature and microcephaly. J Med Genet. 2014;51(9):581-6.

15. Senniappan S, Arya VB, Hussain K. The molecular mechanisms, diagnosis and management of congenital hyperinsulinism. Indian J Endocrinol Metab. 2013;17(1):19-30.

16. Inagaki $\mathrm{N}$, et al. Reconstitution of IKATP: an inward rectifier subunit plus the sulfonylurea receptor. Science. 1995;270(5239): 1166-70.

17. Kapoor RR, et al. Clinical and molecular characterisation of 300 patients with congenital hyperinsulinism. Eur J Endocrinol. 2013;168(4):557-64.

18. Thomas PM, Cote GJ, Wohllk N, Haddad B, Mathew PM, Rabl $\mathrm{W}$, et al. Mutations in the sulfonylurea receptor gene in familial persistent hyperinsulinemic hypoglycemia of infancy. Science. 1995;268(5209):426-9.

19. Thomas P, Ye Y, Lightner E. Mutation of the pancreatic islet inward rectifier Kir6.2 also leads to familial persistent hyperinsulinemic hypoglycemia of infancy. Hum Mol Genet. 1996;5(11):1809-12.

20. Taschenberger G, Mougey A, Shen S, Lester LB, LaFranchi S, Shyng SL. Identification of a familial hyperinsulinism-causing mutation in the sulfonylurea receptor 1 that prevents normal trafficking and function of KATP channels. J Biol Chem. 2002;277(19):17139-46.

21. Huopio H, et al. K(ATP) channels and insulin secretion disorders. Am J Physiol Endocrinol Metab. 2002;283(2):E207-16.

22. Huopio H, Reimann F, Ashfield R, Komulainen J, Lenko HL, Rahier J, et al. Dominantly inherited hyperinsulinism caused by a mutation in the sulfonylurea receptor type 1. J Clin Invest. 2000;106(7):897-906.

23. Huopio H, Otonkoski T, Vauhkonen I, Reimann F, Ashcroft FM, Laakso M. A new subtype of autosomal dominant diabetes attributable to a mutation in the gene for sulfonylurea receptor 1 . Lancet. 2003;361(9354):301-7. 
24. Flanagan SE, Kapoor RR, Banerjee I, Hall C, Smith VV, Hussain $\mathrm{K}$, et al. Dominantly acting ABCC8 mutations in patients with medically unresponsive hyperinsulinaemic hypoglycaemia. Clin Genet. 2011;79(6):582-7.

25. Pinney SE, MacMullen C, Becker S, Lin YW, Hanna C, Thornton $\mathrm{P}$, et al. Clinical characteristics and biochemical mechanisms of congenital hyperinsulinism associated with dominant KATP channel mutations. J Clin Invest. 2008;118(8):2877-86.

26. Kapoor RR, et al. Hyperinsulinaemic hypoglycaemia and diabetes mellitus due to dominant $\mathrm{ABCC} 8 / \mathrm{KCNJ} 11$ mutations. Diabetologia. 2011;54(10):2575-83.

27. Stanley CA, et al. Hyperinsulinism and hyperammonemia in infants with regulatory mutations of the glutamate dehydrogenase gene. N Engl J Med. 1998;338(19):1352-7.

28. Stanley CA, Fang J, Kutyna K, Hsu BY, Ming JE, Glaser B, et al. Molecular basis and characterization of the hyperinsulinism/ hyperammonemia syndrome: predominance of mutations in exons 11 and 12 of the glutamate dehydrogenase gene. HI/HA Contributing Investigators. Diabetes. 2000;49(4):667-73.

29. Kapoor RR, Flanagan SE, Fulton P, Chakrapani A, Chadefaux B, Ben-Omran T, et al. Hyperinsulinism-hyperammonaemia syndrome: novel mutations in the GLUD1 gene and genotypephenotype correlations. Eur J Endocrinol. 2009;161(5):731-5.

30. Glaser B, et al. Familial hyperinsulinism caused by an activating glucokinase mutation. N Engl J Med. 1998;338(4):226-30.

31. Christesen HB, et al. Activating glucokinase (GCK) mutations as a cause of medically responsive congenital hyperinsulinism: prevalence in children and characterisation of a novel GCK mutation. Eur J Endocrinol. 2008;159(1):27-34.

32. Cuesta-Munoz AL, et al. Severe persistent hyperinsulinemic hypoglycemia due to a de novo glucokinase mutation. Diabetes. 2004;53(8):2164-8.

33. Christesen HB, Jacobsen BB, Odili S, Buettger C, Cuesta-Munoz A, Hansen T, et al. The second activating glucokinase mutation (A456V): implications for glucose homeostasis and diabetes therapy. Diabetes. 2002;51(4):1240-6.

34. Heslegrave AJ, et al. Leucine-sensitive hyperinsulinaemic hypoglycaemia in patients with loss of function mutations in 3Hydroxyacyl-CoA dehydrogenase. Orphanet J Rare Dis. 2012;7: 25.

35. Filling C, Keller B, Hirschberg D, Marschall HU, Jörnvall H, Bennett MJ, et al. Role of short-chain hydroxyacyl CoA dehydrogenases in SCHAD deficiency. Biochem Biophys Res Commun. 2008;368(1):6-11.

36. Clayton PT, et al. Hyperinsulinism in short-chain L-3hydroxyacyl-CoA dehydrogenase deficiency reveals the importance of beta-oxidation in insulin secretion. J Clin Invest. 2001;108(3):457-65.

37. Molven A, Matre GE, Duran M, Wanders RJ, Rishaug U, Njølstad $\mathrm{PR}$, et al. Familial hyperinsulinemic hypoglycemia caused by a defect in the SCHAD enzyme of mitochondrial fatty acid oxidation. Diabetes. 2004;53(1):221-7.

38. Kapoor RR, James C, Flanagan SE, Ellard S, Eaton S, Hussain K. 3-Hydroxyacyl-coenzyme a dehydrogenase deficiency and hyperinsulinemic hypoglycemia: characterization of a novel mutation and severe dietary protein sensitivity. J Clin Endocrinol Metab. 2009;94(7):2221-5.

39. Flanagan SE, et al. Genome-wide homozygosity analysis reveals HADH mutations as a common cause of diazoxide-responsive hyperinsulinemic-hypoglycemia in consanguineous pedigrees. $\mathrm{J}$ Clin Endocrinol Metab. 2011;96(3):E498-502.

40. Colclough K, Bellanne-Chantelot C, Saint-Martin C, Flanagan SE, Ellard S. Mutations in the genes encoding the transcription factors hepatocyte nuclear factor 1 alpha and 4 alpha in maturityonset diabetes of the young and hyperinsulinemic hypoglycemia. Hum Mutat. 2013;34(5):669-85.
41. Pearson ER, Boj SF, Steele AM, Barrett T, Stals K, Shield JP, et al. Macrosomia and hyperinsulinaemic hypoglycaemia in patients with heterozygous mutations in the HNF4A gene. PLoS Med. 2007;4(4):e118.

42. Kapoor RR, Locke J, Colclough K, Wales J, Conn JJ, Hattersley AT, et al. Persistent hyperinsulinemic hypoglycemia and maturityonset diabetes of the young due to heterozygous HNF4A mutations. Diabetes. 2008;57(6):1659-63.

43. Flanagan SE, et al. Diazoxide-responsive hyperinsulinemic hypoglycemia caused by HNF4A gene mutations. Eur J Endocrinol. 2010;162(5):987-92.

44. McGlacken-Byrne SM, et al. The evolving course of HNF4A hyperinsulinaemic hypoglycaemia-a case series. Diabet Med. 2014;31(1):e1-5.

45. Stanescu DE, Hughes N, Kaplan B, Stanley CA, de León DD. Novel presentations of congenital hyperinsulinism due to mutations in the MODY genes: HNF1A and HNF4A. J Clin Endocrinol Metab. 2012;97(10):E2026-30.

46. Hamilton AJ, Bingham C, McDonald T, Cook PR, Caswell RC, Weedon MN, et al. The HNF4A R76W mutation causes atypical dominant Fanconi syndrome in addition to a beta cell phenotype. J Med Genet. 2014;51(3):165-9.

47. Numakura C, Hashimoto Y, Daitsu T, Hayasaka K, Mitsui T, Yorifuji T. Two patients with HNF4A-related congenital hyperinsulinism and renal tubular dysfunction: a clinical variation which includes transient hepatic dysfunction. Diabetes Res Clin Pract. 2015;108(3):e53-5.

48. Walsh SB, Unwin R, Kleta R, van't Hoff W, Bass P, Hussain K, et al. Fainting Fanconi syndrome clarified by proxy: a case report. BMC Nephrol. 2017;18(1):230.

49. Rozenkova K, Malikova J, Nessa A, Dusatkova L, Bjørkhaug L, Obermannova B, et al. High incidence of heterozygous ABCC8 and HNF1A mutations in Czech patients with congenital Hyperinsulinism. J Clin Endocrinol Metab. 2015;100(12): E1540-9.

50. Meissner T, Otonkoski T, Feneberg R, Beinbrech B, Apostolidou S, Sipilä I, et al. Exercise induced hypoglycaemic hyperinsulinism. Arch Dis Child. 2001;84(3):254-7.

51. Otonkoski T, Jiao H, Kaminen-Ahola N, Tapia-Paez I, Ullah MS, Parton LE, et al. Physical exercise-induced hypoglycemia caused by failed silencing of monocarboxylate transporter 1 in pancreatic beta cells. Am J Hum Genet. 2007;81(3):467-74.

52. Meissner T, Friedmann B, Okun JG, Schwab MA, Otonkoski T, Bauer T, et al. Massive insulin secretion in response to anaerobic exercise in exercise-induced hyperinsulinism. Horm Metab Res. 2005;37(11):690-4.

53. Fleury $\mathrm{C}$, et al. Uncoupling protein-2: a novel gene linked to obesity and hyperinsulinemia. Nat Genet. 1997;15(3):269-72.

54. González-Barroso MM, et al. Mutations in UCP2 in congenital hyperinsulinism reveal a role for regulation of insulin secretion. PLoS One. 2008;3(12):e3850.

55. Ferrara CT, Boodhansingh KE, Paradies E, Fiermonte G, Steinkrauss LJ, Topor LS, et al. Novel hypoglycemia phenotype in congenital Hyperinsulinism due to dominant mutations of uncoupling protein 2. J Clin Endocrinol Metab. 2017;102(3): 942-9.

56. Laver TW, Weedon MN, Caswell R, Hussain K, Ellard S, Flanagan SE. Analysis of large-scale sequencing cohorts does not support the role of variants in UCP2 as a cause of hyperinsulinaemic hypoglycaemia. Hum Mutat. 2017;38(10): 1442-4.

57. Pinney SE, Ganapathy K, Bradfield J, Stokes D, Sasson A, Mackiewicz K, et al. Dominant form of congenital hyperinsulinism maps to HK1 region on 10q. Horm Res Paediatr. 2013;80(1): $18-27$. 
58. Henquin JC, Sempoux C, Marchandise J, Godecharles S, Guiot Y, Nenquin $\mathrm{M}$, et al. Congenital hyperinsulinism caused by hexokinase I expression or glucokinase-activating mutation in a subset of $\beta$-cells. Diabetes. 2013;62(5):1689-96.

59. Tegtmeyer LC, et al. Multiple phenotypes in phosphoglucomutase 1 deficiency. N Engl J Med. 2014;370(6):533-42.

60. Cabezas OR, Flanagan SE, Stanescu H, García-Martínez E, Caswell R, Lango-Allen H, et al. Polycystic kidney disease with Hyperinsulinemic hypoglycemia caused by a promoter mutation in Phosphomannomutase 2. J Am Soc Nephrol. 2017;28(8):2529 39.

61. Giri D, Vignola ML, Gualtieri A, Scagliotti V, McNamara P, Peak $\mathrm{M}$, et al. Novel FOXA2 mutation causes Hyperinsulinism, hypopituitarism with craniofacial and endoderm-derived organ abnormalities. Hum Mol Genet. 2017;26(22):4315-26.

62. Vajravelu ME, et al. Congenital Hyperinsulinism and hypopituitarism attributable to a mutation in FOXA2. J Clin Endocrinol Metab. 2018;103(3):1042-7.

63. Flanagan SE, Vairo F, Johnson MB, Caswell R, Laver TW, Lango Allen $\mathrm{H}$, et al. A CACNA1D mutation in a patient with persistent hyperinsulinaemic hypoglycaemia, heart defects, and severe hypotonia. Pediatr Diabetes. 2017;18(4):320-3.

64. Gregory LC, Ferreira CB, Young-Baird SK, Williams HJ, Harakalova M, van Haaften G, et al. Impaired EIF2S3 function associated with a novel phenotype of X-linked hypopituitarism with glucose dysregulation. EBioMedicine. 2019;42:470-80.

65. Bufler P, Ehringhaus C, Koletzko S. Dumping syndrome: a common problem following Nissen fundoplication in young children. Pediatr Surg Int. 2001;17(5-6):351-5.

66. Foster-Schubert KE. Hypoglycemia complicating bariatric surgery: incidence and mechanisms. Curr Opin Endocrinol Diabetes Obes. 2011;18(2):129-33.

67. Palladino AA, et al. Increased glucagon-like peptide-1 secretion and postprandial hypoglycemia in children after Nissen fundoplication. J Clin Endocrinol Metab. 2009;94(1):39-44.

68. Hirata Y. Insulin autoimmune syndrome. Nihon Rinsho. 1973;31(7):2227-31.

69. Shin JJ, Gorden P, Libutti SK. Insulinoma: pathophysiology, localization and management. Future Oncol. 2010;6(2):229-37.

70. Ozon A, Demirbilek H, Ertugrul A, Unal S, Gumruk F, Kandemir N. Anemia and neutropenic fever with high dose diazoxide treatment in a case with hyperinsulinism due to Munchausen by proxy. J Pediatr Endocrinol Metab. 2010;23(7):719-23.

71. Toda N, Ihara K, Kojima-Ishii K, Ochiai M, Ohkubo K, Kawamoto Y, et al. Hyperinsulinemic hypoglycemia in Beckwith-Wiedemann, Sotos, and kabuki syndromes: a nationwide survey in Japan. Am J Med Genet A. 2017;173(2):360-7.

72. Henquin JC, Nenquin M, Sempoux C, Guiot Y, BellannéChantelot $\mathrm{C}$, Otonkoski $\mathrm{T}$, et al. In vitro insulin secretion by pancreatic tissue from infants with diazoxide-resistant congenital hyperinsulinism deviates from model predictions. J Clin Invest. 2011;121(10):3932-42.

73. Sempoux C, et al. Morphological Mosaicism of the pancreatic islets: a novel Anatomopathological form of persistent Hyperinsulinemic hypoglycemia of infancy. J Clin Endocrinol Metab. 2011;96(12):3785-93.

74. Damaj L, le Lorch M, Verkarre V, Werl C, Hubert L, NihoulFékété C, et al. Chromosome $11 \mathrm{p} 15$ paternal isodisomy in focal forms of neonatal hyperinsulinism. J Clin Endocrinol Metab. 2008;93(12):4941-7.

75. Rahier J, Fält K, Müntefering H, Becker K, Gepts W, Falkmer S. The basic structural lesion of persistent neonatal hypoglycaemia with hyperinsulinism: deficiency of pancreatic D cells or hyperactivity of B cells? Diabetologia. 1984;26(4):282-9.

76. Rahier J, Guiot Y, Sempoux C. Persistent hyperinsulinaemic hypoglycaemia of infancy: a heterogeneous syndrome unrelated to nesidioblastosis. Arch Dis Child Fetal Neonatal Ed. 2000;82(2): F108-12.

77. Goossens AGW. Saudubray JM, Bonnefont JP, Nihoul-Fekete, Heitz PU, Klöppel G., diffuse and focal nesidioblastosis. A clinicopathological study of 24 patients with persistent neonatal hyperinsulinemic hypoglycemia. Am J Surg Pathol. 1989;3(9): 766-55.

78. Sempoux C, et al. Neonatal hyperinsulinemic hypoglycemia: heterogeneity of the syndrome and keys for differential diagnosis. $\mathrm{J}$ Clin Endocrinol Metab. 1998;83(5):1455-61.

79. Rahier J, et al. Partial or near-total pancreatectomy for persistent neonatal hyperinsulinaemic hypoglycaemia: the pathologist's role. Histopathology. 1998;32(1):15-9.

80. Otonkoski T, et al. Noninvasive diagnosis of focal Hyperinsulinism of infancy with [18F]-DOPA positron emission tomography. Diabetes. 2006;55(1):13-8.

81. Sempoux C, Guiot Y, Jaubert F, Rahier J. Focal and diffuse forms of congenital hyperinsulinism: the keys for differential diagnosis. Endocr Pathol. 2004;15(3):241-6.

82. Hussain K, et al. An ABCC8 gene mutation and mosaic uniparental isodisomy resulting in atypical diffuse congenital hyperinsulinism. Diabetes. 2008;57(1):259-63.

83. Henquin JC, Sempoux C, Marchandise J, Godecharles S, Guiot Y, Nenquin $\mathrm{M}$, et al. Congenital hyperinsulinism caused by hexokinase I expression or glucokinase-activating mutation in a subset of beta-cells. Diabetes. 2013;62(5):1689-96.

84. Shi Y, Avatapalle HB, Skae MS, Padidela R, Newbould M, Rigby $\mathrm{L}$, et al. Increased plasma Incretin concentrations identifies a subset of patients with persistent congenital Hyperinsulinism without KATP Channel gene defects. J Pediatr. 2015;166(1):191-4.

85. Hussain K. Investigations for neonatal hypoglycaemia. Clin Biochem. 2011;44(7):465-6.

86. Aynsley-Green A, Hussain K, Hall J, Saudubray JM, NihoulFékété C, de Lonlay-Debeney $\mathrm{P}$, et al. Practical management of hyperinsulinism in infancy. Arch Dis Child Fetal Neonatal Ed. 2000;82(2):F98-F107.

87. Yorifuji T, Horikawa R, Hasegawa T, Adachi M, Soneda S, Minagawa M, et al. Clinical practice guidelines for congenital hyperinsulinism. Clin Pediatr Endocrinol. 2017;26(3):127-52.

88. Palladino AA, Bennett MJ, Stanley CA. Hyperinsulinism in infancy and childhood: when an insulin level is not always enough. Clin Chem. 2008;54(2):256-63.

89. Al-Otaibi $\mathrm{H}$, et al. Biochemical studies in patients with hyperinsulinaemic hypoglycaemia. Eur J Pediatr. 2013;172(11): 1435-40.

90. Ferrara C, et al. Biomarkers of insulin for the diagnosis of Hyperinsulinemic hypoglycemia in infants and children. $\mathrm{J}$ Pediatr. 2016;168:212-9.

91. Brun JF, Fédou C, Bouix O, Raynaud E, Orsetti A. Evaluation of a standardized hyperglucidic breakfast test in postprandial reactive hypoglycaemia. Diabetologia. 1995;38(4):494-501.

92. Otonkoski T, Kaminen N, Ustinov J, Lapatto R, Meissner T, Mayatepek E, et al. Physical exercise-induced hyperinsulinemic hypoglycemia is an autosomal-dominant trait characterized by abnormal pyruvate-induced insulin release. Diabetes. 2003;52(1):199-204.

93. Alsaffar $\mathrm{H}$, et al. Continuous flash glucose monitoring in children with congenital Hyperinsulinism; first report on accuracy and patient experience. Int J Pediatr Endocrinol. 2018;2018:3.

94. Meintjes M, Endozo R, Dickson J, Erlandsson K, Hussain K, Townsend C, et al. 18F-DOPA PET and enhanced CT imaging for congenital hyperinsulinism: initial UK experience from a technologist's perspective. Nucl Med Commun. 2013;34(6):601-8.

95. Lord K, et al. Clinical presentation and management of children with diffuse and focal hyperinsulinism: a review of 223 cases. J Clin Endocrinol Metab. 2013;98(11):E1786-9. 
96. Blomberg BA, et al. The value of radiologic interventions and (18)F-DOPA PET in diagnosing and localizing focal congenital hyperinsulinism: systematic review and meta-analysis. Mol Imaging Biol. 2013;15(1):97-105.

97. Ismail D, Kapoor RR, Smith VV, Ashworth M, Blankenstein O, Pierro A, et al. The heterogeneity of focal forms of congenital hyperinsulinism. J Clin Endocrinol Metab. 2012;97(1):E94-9.

98. Hardy OT, et al. Accuracy of [18F]fluorodopa positron emission tomography for diagnosing and localizing focal congenital hyperinsulinism. J Clin Endocrinol Metab. 2007;92(12):4706-11.

99. Banerjee I, Avatapalle B, Padidela R, Stevens A, Cosgrove KE, Clayton PE, et al. Integrating genetic and imaging investigations into the clinical management of congenital hyperinsulinism. Clin Endocrinol. 2013;78(6):803-13.

100. Ribeiro MJ, Boddaert N, Delzescaux T, Valayannopoulos V, Bellanné-Chantelot C, Jaubert F, et al. Functional imaging of the pancreas: the role of [18F]fluoro-L-DOPA PET in the diagnosis of hyperinsulinism of infancy. Endocr Dev. 2007;12:55-66.

101. Barthlen W, et al. Evaluation of [18F]fluoro-L-DOPA positron emission tomography-computed tomography for surgery in focal congenital hyperinsulinism. J Clin Endocrinol Metab. 2008;93(3): 869-75.

102. Zani A, et al. The predictive value of preoperative fluorine-18-L-3, 4-dihydroxyphenylalanine positron emission tomographycomputed tomography scans in children with congenital hyperinsulinism of infancy. J Pediatr Surg. 2011;46(1):204-8.

103. Capito C, Khen-Dunlop N, Ribeiro MJ, Brunelle F, Aigrain Y, Crétolle C, et al. Value of 18F-fluoro-L-dopa PET in the preoperative localization of focal lesions in congenital hyperinsulinism. Radiology. 2009;253(1):216-22.

104. Treglia G, Mirk P, Giordano A, Rufini V. Diagnostic performance of fluorine-18-dihydroxyphenylalanine positron emission tomography in diagnosing and localizing the focal form of congenital hyperinsulinism: a meta-analysis. Pediatr Radiol. 2012;42(11): 1372-9.

105. Garg PK, et al. Pancreatic uptake and radiation dosimetry of 6[18F]fluoro-L-DOPA from PET imaging studies in infants with congenital hyperinsulinism. PLoS One. 2017;12(11):e0186340.

106. Maines E, Giacomello L, D'Onofrio M, Salgarello M, Gaudino R, Baggio L, et al. Images from. Nucl Med Mol Imaging. 2017;51(4): 362-3.

107. Kühnen P, Matthae R, Arya V, Hauptmann K, Rothe K, Wächter $\mathrm{S}$, et al. Occurrence of giant focal forms of congenital hyperinsulinism with incorrect visualization by (18) F DOPA-PET/CT scanning. Clin Endocrinol. 2014;81(6):847-54.

108. Parihar AS, et al. 68Ga DOTA-Exendin PET/CT for detection of Insulinoma in a patient with persistent Hyperinsulinemic hypoglycemia. Clin Nucl Med. 2018;43(8):e285-e286.

109. Cuthbertson DJ, Banks M, Khoo B, Antwi K, Christ E, Campbell F, et al. Application of Ga(68) -DOTA-exendin-4 PET/CT to localize an occult insulinoma. Clin Endocrinol. 2016;84(5):789-91.

110. Tuzcu SA, Pekkolay Z, Kılınç F, Tuzcu AK. Ga-DOTATATE $\mathrm{PET} / \mathrm{CT}$ can be an alternative imaging method in Insulinoma patients. J Nucl Med Technol. 2017;45(3):198-200.

111. Deppen SA, Blume J, Bobbey AJ, Shah C, Graham MM, Lee P, et al. 68Ga-DOTATATE compared with $111 \mathrm{In}$-DTPA-Octreotide and conventional imaging for pulmonary and Gastroenteropancreatic neuroendocrine tumors: a systematic review and meta-analysis. J Nucl Med. 2016;57(6):872-8.

112. Sharma P, et al. Somatostatin receptor based PET/CT imaging with 68Ga-DOTA-Nal3-octreotide for localization of clinically and biochemically suspected insulinoma. Q J Nucl Med Mol Imaging. 2016;60(1):69-76.

113. Hussain K, Blankenstein O, de Lonlay $\mathrm{P}$, Christesen HT. Hyperinsulinaemic hypoglycaemia: biochemical basis and the importance of maintaining normoglycaemia during management. Arch Dis Child. 2007;92(7):568-70.

114. Nebesio TD, Hoover WC, Caldwell RL, Nitu ME, Eugster EA. Development of pulmonary hypertension in an infant treated with diazoxide. J Pediatr Endocrinol Metab. 2007;20(8):939-44.

115. Timlin MR, Black AB, Delaney HM, Matos RI, Percival CS. Development of pulmonary hypertension during treatment with Diazoxide: a case series and literature review. Pediatr Cardiol. 2017;38(6):1247-50.

116. Chen SC, Dastamani A, Pintus D, Yau D, Aftab S, Bath L, et al. Diazoxide-induced pulmonary hypertension in hyperinsulinaemic hypoglycaemia: Recommendations from a multicentre study in the United Kingdom. Clin Endocrinol. 2019;91(6):770-775.

117. Arnoux JB, et al. Congenital hyperinsulinism: current trends in diagnosis and therapy. Orphanet J Rare Dis. 2011;6:63.

118. Müller D, Zimmering M, Roehr CC. Should nifedipine be used to counter low blood sugar levels in children with persistent hyperinsulinaemic hypoglycaemia? Arch Dis Child. 2004;89(1): 83-5.

119. Baş F, et al. Successful therapy with calcium channel blocker (nifedipine) in persistent neonatal hyperinsulinemic hypoglycemia of infancy. J Pediatr Endocrinol Metab. 1999;12(6):873-8.

120. Shanbag P, Pathak A, Vaidya M, Shahid SK. Persistent hyperinsulinemic hypoglycemia of infancy-successful therapy with nifedipine. Indian J Pediatr. 2002;69(3):271-2.

121. Eichmann D, Hufnagel M, Quick P, Santer R. Treatment of hyperinsulinaemic hypoglycaemia with nifedipine. Eur J Pediatr. 1999; 158(3):204-6.

122. Welters A, et al. Long-term medical treatment in congenital hyperinsulinism: a descriptive analysis in a large cohort of patients from different clinical centers. Orphanet J Rare Dis. 2015;10:150.

123. Güemes M, Shah P, Silvera S, Morgan K, Gilbert C, Hinchey L, et al. Assessment of Nifedipine therapy in Hyperinsulinemic hypoglycemia due to mutations in the $\mathrm{ABCC} 8$ gene. J Clin Endocrinol Metab. 2017;102(3):822-30.

124. Durmaz E, Flanagan SE, Parlak M, Ellard S, Akcurin S, Bircan I. A combination of nifedipine and octreotide treatment in an hyperinsulinemic hypoglycemic infant. J Clin Res Pediatr Endocrinol. 2014;6(2):119-21.

125. Glaser B, Hirsch HJ, Landau H. Persistent hyperinsulinemic hypoglycemia of infancy: long-term octreotide treatment without pancreatectomy. J Pediatr. 1993;123(4):644-50.

126. Thornton PS, Alter CA, Katz LE, Baker L, Stanley CA. Short- and long-term use of octreotide in the treatment of congenital hyperinsulinism. J Pediatr. 1993;123(4):637-43.

127. Roženková K, et al. The diagnosis and Management of Hyperinsulinaemic Hypoglycaemia. J Clin Res Pediatr Endocrinol. 2015;7(2):86-97.

128. Mohnike K, Blankenstein O, Pfuetzner A, Pötzsch S, Schober E, Steiner S, et al. Long-term non-surgical therapy of severe persistent congenital hyperinsulinism with glucagon. Horm Res. 2008;70(1):59-64.

129. Brun JF, Fedou C, Mercier J. Postprandial reactive hypoglycemia. Diabetes Metab. 2000;26(5):337-51.

130. Salvatore T, Giugliano D. Pharmacokinetic-pharmacodynamic relationships of Acarbose. Clin Pharmacokinet. 1996;30(2):94-106.

131. Le Quan Sang KH, et al. Successful treatment of congenital hyperinsulinism with long-acting release octreotide. Eur J Endocrinol. 2012;166(2):333-9.

132. Modan-Moses D, Koren I, Mazor-Aronovitch K, Pinhas-Hamiel $\mathrm{O}$, Landau H. Treatment of congenital hyperinsulinism with lanreotide acetate (Somatuline autogel). J Clin Endocrinol Metab. 2011;96(8):2312-7.

133. Shah P, Rahman SA, McElroy S, Gilbert C, Morgan K, Hinchey $\mathrm{L}$, et al. Use of long-acting Somatostatin analogue (Lanreotide) in an adolescent with Diazoxide-responsive congenital 
Hyperinsulinism and its psychological impact. Horm Res Paediatr. 2015;84(5):355-60.

134. Kühnen $P$, et al. Long-term lanreotide treatment in six patients with congenital hyperinsulinism. Horm Res Paediatr. 2012;78(2):106-12.

135. van der Steen I, van Albada M, Mohnike K, Christesen HT, Empting S, Salomon-Estebanez M, et al. A multicenter experience with long-acting Somatostatin analogues in patients with congenital Hyperinsulinism. Horm Res Paediatr. 2018;89(2):82-9.

136. Corda $\mathrm{H}$, et al. Treatment with long-acting lanreotide autogel in early infancy in patients with severe neonatal hyperinsulinism. Orphanet J Rare Dis. 2017;12(1):108.

137. Dastamani A, Güemes M, Pitfield C, Morgan K, Rajab M, Rottenburger $\mathrm{C}$, et al. The use of a long-acting Somatostatin analogue (Lanreotide) in three children with focal forms of congenital Hyperinsulinaemic Hypoglycaemia. Horm Res Paediatr. 2019;91(1):56-61.

138. Kulke MH, Bergsland EK, Yao JC. Glycemic control in patients with insulinoma treated with everolimus. N Engl J Med. 2009;360(2):195-7.

139. Alexandrescu S, et al. Persistent hyperinsulinemic hypoglycemia of infancy: constitutive activation of the mTOR pathway with associated exocrine-islet transdifferentiation and therapeutic implications. Int J Clin Exp Pathol. 2010;3(7):691-705.

140. Senniappan S, Alexandrescu S, Tatevian N, Shah P, Arya V, Flanagan S, et al. Sirolimus therapy in infants with severe hyperinsulinemic hypoglycemia. N Engl J Med. 2014;370(12): $1131-7$.

141. Guemes M, et al. Severe Hyperinsulinaemic Hypoglycaemia in Beckwith-Wiedemann syndrome due to paternal Uniparental Disomy of 11p15.5 managed with Sirolimus therapy. Horm Res Paediatr. 2016;85(5):353-7.

142. Shah P, Arya VB, Flanagan SE, Morgan K, Ellard S, Senniappan $S$, et al. Sirolimus therapy in a patient with severe hyperinsulinaemic hypoglycaemia due to a compound heterozygous ABCC8 gene mutation. J Pediatr Endocrinol Metab. 2015;28(5-6):695-9.

143. Al-Balwi R, et al. Sirolimus in the treatment of three infants with diffuse congenital hyperinsulinism. J Pediatr Endocrinol Metab. 2017;30(9):1013-7.

144. Minute M, et al. Sirolimus therapy in congenital Hyperinsulinism: a successful experience beyond infancy. Pediatrics. 2015;136(5): e1373-6.

145. Méder Ü, et al. Severe Hyperinsulinemic hypoglycemia in a neonate: response to Sirolimus therapy. Pediatrics. 2015;136(5): e1369-72.

146. Haliloğlu B, Tüzün H, Flanagan SE, et al. Sirolimus-Induced hepatitis in two patients with hyperinsulinemic hypoglycemia. J Clin Res Pediatr Endocrinol. 2018;10(3):279-283.

147. Dastamani A, Güemes M, Walker J, Shah P, Hussain K. Sirolimus precipitating diabetes mellitus in a patient with congenital hyperinsulinaemic hypoglycaemia due to autosomal dominant ABCC8 mutation. J Pediatr Endocrinol Metab. 2017;30(11): 1219-22.

148. Szymanowski M, Estebanez MS, Padidela R, Han B, Mosinska K, Stevens A, et al. mTOR inhibitors for the treatment of severe congenital Hyperinsulinism: perspectives on limited therapeutic success. J Clin Endocrinol Metab. 2016;101(12):4719-29.

149. Banerjee I, De Leon D, Dunne MJ. Extreme caution on the use of sirolimus for the congenital hyperinsulinism in infancy patient. Orphanet J Rare Dis. 2017;12(1):70.

150. Maria G, Antonia D, Michael A, Kate M, Sian E, Sarah FE, et al. Sirolimus: efficacy and complications in children with Hyperinsulinemic hypoglycemia: a 5-year follow-up study. J Endocr Soc. 2019;3(4):699-713.
151. McClenaghan NH, Flatt PR, Ball AJ. Actions of glucagon-like peptide-1 on KATP channel-dependent and -independent effects of glucose, sulphonylureas and nateglinide. J Endocrinol. 2006;190(3):889-96.

152. De León DD, et al. Exendin-(9-39) corrects fasting hypoglycemia in SUR-1-/- mice by lowering cAMP in pancreatic beta-cells and inhibiting insulin secretion. J Biol Chem. 2008;283(38):2578693.

153. Calabria AC, Li C, Gallagher PR, Stanley CA, de León DD. GLP1 receptor antagonist exendin-(9-39) elevates fasting blood glucose levels in congenital hyperinsulinism owing to inactivating mutations in the ATP-sensitive $\mathrm{K}+$ channel. Diabetes. 2012;61(10):2585-91.

154. Chen PC, Olson EM, Zhou Q, Kryukova Y, Sampson HM, Thomas DY, et al. Carbamazepine as a novel small molecule corrector of trafficking-impaired ATP-sensitive potassium channels identified in congenital hyperinsulinism. J Biol Chem. 2013;288(29):20942-54.

155. Yan F, Lin CW, Weisiger E, Cartier EA, Taschenberger G, Shyng SL. Sulfonylureas correct trafficking defects of ATP-sensitive potassium channels caused by mutations in the sulfonylurea receptor. J Biol Chem. 2004;279(12):11096-105.

156. Devaraneni PK, Martin GM, Olson EM, Zhou Q, Shyng SL. Structurally distinct ligands rescue biogenesis defects of the KATP channel complex via a converging mechanism. J Biol Chem. 2015;290(12):7980-91.

157. Martin GM, Rex EA, Devaraneni P, Denton JS, Boodhansingh KE, DeLeon D, et al. Pharmacological correction of trafficking defects in ATP-sensitive potassium channels caused by sulfonylurea receptor 1 mutations. J Biol Chem. 2016;291(42):21971-83.

158. Neylon OM, Moran MM, Pellicano A, Nightingale M, O'Connell MA. Successful subcutaneous glucagon use for persistent hypoglycaemia in congenital hyperinsulinism. J Pediatr Endocrinol Metab. 2013;26(11-12):1157-61.

159. Hövelmann U, Bysted BV, Mouritzen U, Macchi F, Lamers D, Kronshage B, et al. Pharmacokinetic and Pharmacodynamic characteristics of Dasiglucagon, a novel soluble and stable glucagon analog. Diabetes Care. 2018;41(3):531-7.

160. Laguna Sanz AJ, Mulla CM, Fowler KM, Cloutier E, Goldfine $\mathrm{AB}$, Newswanger B, et al. Design and clinical evaluation of a novel low-glucose prediction algorithm with mini-dose stable glucagon delivery in post-bariatric hypoglycemia. Diabetes Technol Ther. 2018;20(2):127-39.

161. Pierro A, Nah SA. Surgical management of congenital hyperinsulinism of infancy. Semin Pediatr Surg. 2011;20(1):50-3

162. Adzick NS, Thornton PS, Stanley CA, Kaye RD, Ruchelli E. A multidisciplinary approach to the focal form of congenital hyperinsulinism leads to successful treatment by partial pancreatectomy. J Pediatr Surg. 2004;39(3):270-5.

163. Al-Shanafey S. Laparoscopic vs open pancreatectomy for persistent hyperinsulinemic hypoglycemia of infancy. J Pediatr Surg. 2009;44(5):957-61.

164. Laje $P$, et al. Pancreatic head resection and roux-en-Y pancreaticojejunostomy for the treatment of the focal form of congenital hyperinsulinism. J Pediatr Surg. 2012;47(1):130-5.

165. Beltrand J, Caquard M, Arnoux JB, Laborde K, Velho G, Verkarre $\mathrm{V}$, et al. Glucose metabolism in 105 children and adolescents after pancreatectomy for congenital hyperinsulinism. Diabetes Care. 2012;35(2):198-203.

166. Arya VB, Senniappan S, Demirbilek H, Alam S, Flanagan SE, Ellard S, et al. Pancreatic endocrine and exocrine function in children following near-total pancreatectomy for diffuse congenital hyperinsulinism. PLoS One. 2014;9(5):e98054.

167. Shah P, Demirbilek H, Hussain K. Persistent hyperinsulinaemic hypoglycaemia in infancy. Semin Pediatr Surg. 2014;23(2):76-82. 
168. Gouya H, Vignaux O, Augui J, Dousset B, Palazzo L, Louvel A, et al. CT, endoscopic sonography, and a combined protocol for preoperative evaluation of pancreatic insulinomas. AJR Am J Roentgenol. 2003;181(4):987-92.

169. Iglesias P, Lafuente C, Martín Almendra MÁ, López Guzmán A, Castro JC, Díez JJ. Insulinoma: a multicenter, retrospective analysis of three decades of experience (1983-2014). Endocrinol Nutr. 2015;62(7):306-13.

170. Okabayashi T, Shima Y, Sumiyoshi T, Kozuki A, Ito S, Ogawa Y, et al. Diagnosis and management of insulinoma. World J Gastroenterol. 2013;19(6):829-37.

171. Antonakis PT, Ashrafian H, Martinez-Isla A. Pancreatic insulinomas: laparoscopic management. World J Gastrointest Endosc. 2015;7(16):1197-207.

172. Ito T, Igarashi H, Jensen RT. Pancreatic neuroendocrine tumors: clinical features, diagnosis and medical treatment: advances. Best Pract Res Clin Gastroenterol. 2012;26(6):737-53.

173. Salomon-Estebanez M, Flanagan SE, Ellard S, Rigby L, Bowden L, Mohamed Z, et al. Conservatively treated congenital Hyperinsulinism (CHI) due to K-ATP channel gene mutations: reducing severity over time. Orphanet J Rare Dis. 2016;11(1):163.

174. Sun L, Coy DH. Somatostatin and its analogs. Curr Drug Targets. 2016;17(9):529-537.

175. Demirbilek H, Shah P, Arya VB, Hinchey L, Flanagan SE, Ellard $\mathrm{S}$, et al. Long-term follow-up of children with congenital hyperinsulinism on octreotide therapy. J Clin Endocrinol Metab. 2014;99(10):3660-7.

176. Lord K, et al. High risk of diabetes and neurobehavioral deficits in individuals with surgically treated Hyperinsulinism. J Clin Endocrinol Metab. 2015;100(11):4133-9.

177. Ludwig A, et al. Formal neurocognitive testing in 60 patients with congenital Hyperinsulinism. Horm Res Paediatr. 2018;89(1):1-6.

178. NICE, NG43. Transition from children's to adults' services for young people using health or social care services. https://www. nice.org.uk/guidance/ng43/resources. Accessed 1 Feb 2016.

179. Lotstein DS, et al. Transition from pediatric to adult care for youth diagnosed with type 1 diabetes in adolescence. Pediatrics. 2013;131(4):e1062-70.

180. Viner R. Transition from paediatric to adult care. Bridging the gaps or passing the buck? Arch Dis Child. 1999;81(3):271-5.

181. Zhou H, Roberts P, Dhaliwal S, Della P. Transitioning adolescent and young adults with chronic disease and/or disabilities from paediatric to adult care services - an integrative review. J Clin Nurs. 2016;25(21-22):3113-30.

182. de Silva PS, Fishman LN. Transition of the patient with IBD from pediatric to adult care-an assessment of current evidence. Inflamm Bowel Dis. 2014;20(8):1458-64.

183. Borus JS, Laffel L. Adherence challenges in the management of type 1 diabetes in adolescents: prevention and intervention. Curr Opin Pediatr. 2010;22(4):405-11.

184. Valenzuela JM, Buchanan CL, Radcliffe J, Ambrose C, Hawkins LA, Tanney M, et al. Transition to adult services among behaviorally infected adolescents with HIV-a qualitative study. J Pediatr Psychol. 2011;36(2):134-40.

185. Hanna KM, Woodward J. The transition from pediatric to adult diabetes care services. Clin Nurse Spec. 2013;27(3):132-45.

186. van Staa A, Sattoe JN. Young adults' experiences and satisfaction with the transfer of care. J Adolesc Health. 2014;55(6):796-803.

187. Barlow J, et al. Self-management approaches for people with chronic conditions: a review. Patient Educ Couns. 2002;48(2): 177-87.

188. Acuña Mora M, Sparud-Lundin C, Bratt EL, Moons P. Personcentred transition programme to empower adolescents with congenital heart disease in the transition to adulthood: a study protocol for a hybrid randomised controlled trial (STEPSTONES project). BMJ Open. 2017;7(4):e014593.

189. Turkel S, Pao M. Late consequences of chronic pediatric illness. Psychiatr Clin North Am. 2007;30(4):819-35.

190. Peters A, Laffel L, A.D.A.T.W. Group. Diabetes care for emerging adults: recommendations for transition from pediatric to adult diabetes care systems: a position statement of the American Diabetes Association, with representation by the American College of Osteopathic Family Physicians, the American Academy of Pediatrics, the American Association of Clinical Endocrinologists, the American Osteopathic Association, the Centers for Disease Control and Prevention, Children with Diabetes, The Endocrine Society, the International Society for Pediatric and Adolescent Diabetes, Juvenile Diabetes Research Foundation International, the National Diabetes Education Program, and the Pediatric Endocrine Society (formerly Lawson Wilkins Pediatric Endocrine Society). Diabetes Care. 2011;34(11):2477-85.

191. Choudhary P, Amiel SA. Hypoglycaemia in type 1 diabetes: technological treatments, their limitations and the place of psychology. Diabetologia. 2018;61(4):761-9.

192. Clarke WL, Cox DJ, Gonder-Frederick LA, Julian D, Schlundt D, Polonsky W. Reduced awareness of hypoglycemia in adults with IDDM. A prospective study of hypoglycemic frequency and associated symptoms. Diabetes Care. 1995;18(4):517-22.

193. Gold AE, MacLeod KM, Frier BM. Frequency of severe hypoglycemia in patients with type I diabetes with impaired awareness of hypoglycemia. Diabetes Care. 1994;17(7):697-703.

194. Hay WW, et al. Knowledge gaps and research needs for understanding and treating neonatal hypoglycemia: workshop report from Eunice Kennedy Shriver National Institute of Child Health and Human Development. J Pediatr. 2009;155(5):612-7.

195. DVLA Assessing fitness to drive - a guide for medical. professionals [Internet]. May 20, 2018.

196. Wallis C. Transition of care in children with chronic disease. BMJ. 2007;334(7606):1231-2.

197. Rosenbaum P, Stewart D. Perspectives on transitions: rethinking services for children and youth with developmental disabilities. Arch Phys Med Rehabil. 2007;88(8):1080-2.

198. Cannarella R, Arato I, Condorelli RA, et al. Effects of insulin on porcine neonatal sertoli cell responsiveness to FSH In Vitro. J Clin Med. 2019;8(6):809.

199. Garvey KC, Wolpert HA, Laffel LM, Rhodes ET, Wolfsdorf JI, Finkelstein JA. Health care transition in young adults with type 1 diabetes: barriers to timely establishment of adult diabetes care. Endocr Pract. 2013;19(6):946-52.

200. Johnson SR, Leo PJ, McInerney-Leo A, Anderson LK, Marshall $\mathrm{M}$, McGown I, et al. Whole-exome sequencing for mutation detection in pediatric disorders of insulin secretion: maturity onset diabetes of the young and congenital hyperinsulinism. Pediatr Diabetes. 2018;19(4):656-62.

201. Shah P, et al. Hyperinsulinaemic hypoglycaemia in children and adults. Lancet Diabetes Endocrinol. 2017;5(9):729-42.

202. Corbin JA, Bhaskar V, Goldfine ID, Issafras H, Bedinger DH, Lau A, et al. Inhibition of insulin receptor function by a human, allosteric monoclonal antibody: a potential new approach for the treatment of hyperinsulinemic hypoglycemia. MAbs. 2014;6(1):26272 .

203. Kapoor RR, James C, Hussain K. Hyperinsulinism in developmental syndromes. Endocr Dev. 2009;14:95-113.

Publisher's note Springer Nature remains neutral with regard to jurisdictional claims in published maps and institutional affiliations. 